In cooperation with the Pike Lake Protection and Rehabilitation District

\title{
Water Quality, Hydrology, and the Effects of Changes in Phosphorus Loading to Pike Lake, Washington County, Wisconsin, with Special Emphasis on Inlet-to-Outlet Short-Circuiting
}

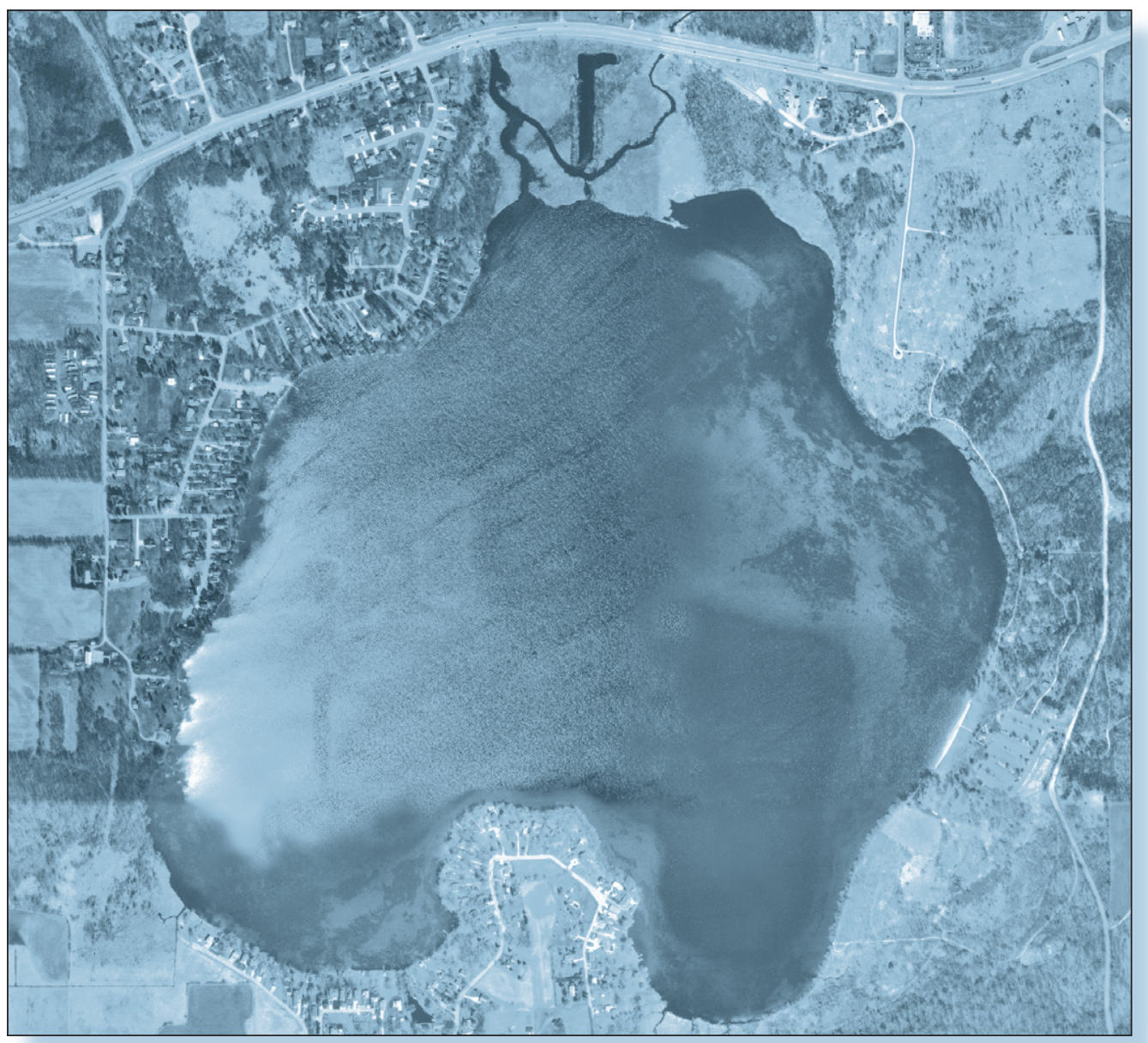

Scientific Investigations Report 2004 -5141 


\section{Water Quality, Hydrology, and the Effects of Changes in Phosphorus Loading to Pike Lake, Washington County, Wisconsin, with Special Emphasis on Inlet-to-Outlet Short-Circuiting}

By William J. Rose, Dale M. Robertson, and Elizabeth A. Mergener

In cooperation with the Pike Lake Protection and Rehabilitation District

Scientific Investigations Report 2004-5141 


\title{
U.S. Department of the Interior
}

Gale A. Norton, Secretary

\section{U.S. Geological Survey \\ Charles G. Groat, Director}

U.S. Geological Survey, Reston, Virginia: 2004

\author{
For sale by U.S. Geological Survey, Information Services \\ Box 25286, Denver Federal Center \\ Denver, CO 80225 \\ For more information about the USGS and its products: \\ Telephone: 1-888-ASK-USGS \\ World Wide Web: http://www.usgs.gov/
}

Any use of trade, product, or firm names in this publication is for descriptive purposes only and does not imply endorsement by the U.S. Government. 


\section{Contents}

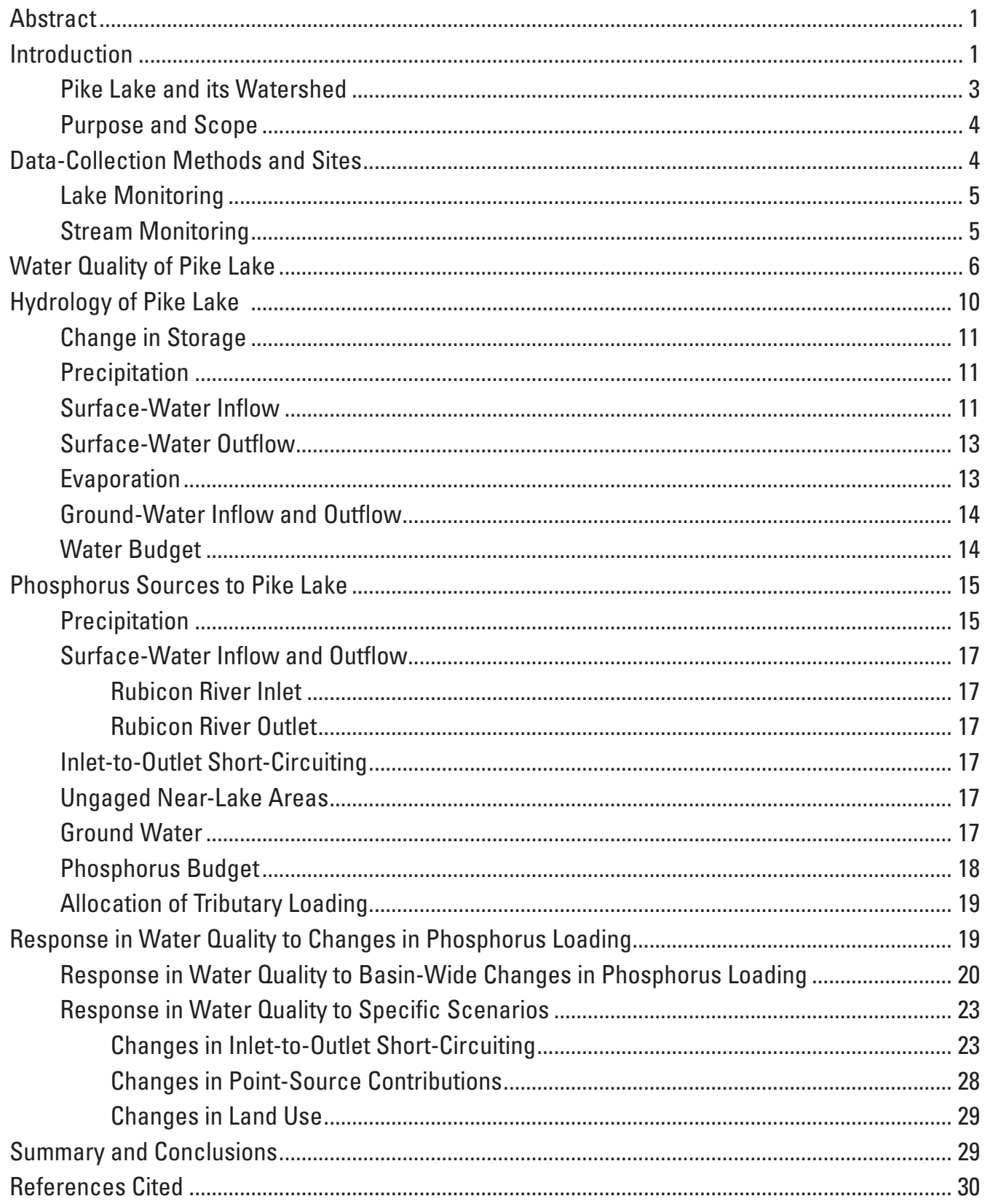




\section{Figures}

1-2. Maps showing:

1. Drainage basin of Pike Lake, Wis 2

2. Locations and types of data-collection sites at or near Pike Lake, Wis. 4

3-17. Graphs showing:

3. Trends in chloride and sodium concentrations in Pike Lake near Hartford, Wis., 1960-2000

4. Measured Secchi depths, and total phosphorus and chlorophyll a concentrations, and summer (June through September) average values at the deep hole in Pike Lake near Hartford, Wis., 1973-2001

5. Trophic state index (TSI) values based on surface concentrations of total phosphorus and chlorophyll $a$, and Secchi depths for Pike Lake, near Hartford, Wis., 1973-2002

6. Measured and calculated daily water levels of Pike Lake near Hartford, Wis., December 1998-November 2000

7. Precipitation at Pike Lake, Wis., during December 1998-November 2000 relative to long-term average precipitation at Hartford, Wis.

8. Daily average flow and instantaneous phosphorus concentrations in the Rubicon River at the inlet to Pike Lake near Hartford, Wis., December 1998 through November 2000

9. Daily average flow and instantaneous phosphorus concentrations in the Rubicon River at the outlet of Pike Lake and surface phosphorus concentration at the deepest location in the lake, December 1998 through November 2000

10. Water budget for Pike Lake, near Hartford, Wis., for monitoring years 1999 and 2000

11. Daily phosphorus loads at the Rubicon River inlet to and outlet from Pike Lake, Wis., and the estimated part of inlet load short-circuited from the inlet to the outlet, December 1998-November 2000

12. Phosphorus budgets for Pike Lake, near Hartford, Wis., for monitoring years 1999 and 2000

13. Allocation of phosphorus load on the basis of land use/land cover to Pike Lake, near Hartford, Wis., for 2000.

14. Simulated changes in near-surface total phosphorus concentrations in Pike Lake near Hartford, Wis., with WiLMS (Wisconsin Lake Modeling Suite) in response to various phosphorus-loading scenarios.

15. Simulated changes in near-surface chlorophyll a concentrations in Pike Lake near Hartford, Wis., with WiLMS (Wisconsin Lake Modeling Suite) in response to various phosphorus-loading scenarios.

16. Simulated changes in Secchi depths in Pike Lake near Hartford, Wis., with WiLMS (Wisconsin Lake Modeling Suite) in response to various phosphorusloading scenarios

17. Simulated changes in trophic state index values for Pike Lake near Hartford, Wis., with WiLMS (Wisconsin Lake Modeling Suite) in response to various phosphorus-loading scenarios 


\section{Tables}

1. Land use/land cover in the Pike Lake watershed from the WISCLAND geographic information system coverage...................................................................... 3

2. Average summer (June through September) water quality and trophic state index (TSI) values for Pike Lake 7

3. Water budget for Pike Lake near Hartford, Wis., monitoring years 1999 and 2000 12

4. Phosphorus budget for Pike Lake near Hartford, Wis., monitoring years 1999 and 2000 .

5. Allocation of phosphorus loading to land-use/land-cover categories in the Pike Lake watershed

6. Contributions of phosphorus, by source, for various phosphorus-loading scenarios for Pike Lake near Hartford, Wis.

7. Estimated phosphorus concentrations in Pike Lake near Hartford, Wis., in response to various phosphorus-loading scenarios on the basis of models within the Wisconsin Lakes Modeling Suite (WiLMS)

8. Estimated chlorophyll a concentrations and Secchi depths based on predicted phosphorus concentrations 


\section{Conversion Factors and Abbreviated Water-Quality Units}

\begin{tabular}{lcl}
\hline \multicolumn{1}{c}{ Multiply } & By & \multicolumn{1}{c}{ To obtain } \\
\hline inch (in.) & Length & \\
foot (ft) & 25.4 & millimeter $(\mathrm{mm})$ \\
mile (mi) & 0.3048 & meter $(\mathrm{m})$ \\
\hline \multicolumn{3}{c}{ kilometer $(\mathrm{km})$} \\
\hline acre & 1.609 & \\
square mile $\left(\mathrm{mi}^{2}\right)$ & Area & square kilometer $\left(\mathrm{km}^{2}\right)$ \\
\hline & 0.004047 & square kilometer $\left(\mathrm{km}^{2}\right)$ \\
\hline acre-foot (acre-ft) & 2.590 & \\
\hline \multicolumn{3}{c}{ Volume } \\
\hline inch per year (in/yr) & 1,233 & cubic meter $\left(\mathrm{m}^{3}\right)$ \\
pound, avoirdupois (lb) & Flow rate & \\
\hline & 25.4 & millimeter per year $(\mathrm{mm} / \mathrm{yr})$ \\
\hline pounds per acre per year & 0.4536 & kilogram $(\mathrm{kg})$ \\
[(lb/acre)/yr] & Application rate & \\
\hline
\end{tabular}

Temperature, in degrees Celsius $\left({ }^{\circ} \mathrm{C}\right)$ can be converted to degrees Fahrenheit $\left({ }^{\circ} \mathrm{F}\right)$ as follows:

$$
{ }^{\circ} \mathrm{F}=\left[1.8 \mathrm{x}^{\circ} \mathrm{C}\right]+32 \text {. }
$$

Monitoring year: Monitoring year is defined as the period beginning December 1 and ending November 30 , designated by the calendar year in which it ends.

Abbreviated water-quality units used in this report: Chemical concentrations and water temperature are given in metric units. Chemical concentration is given in milligrams per liter ( $\mathrm{mg} / \mathrm{L})$ or micrograms per liter ( $\mu \mathrm{g} / \mathrm{L})$. Milligrams per liter is a unit expressing the concentration of chemical constituents in solution as weight (milligrams) of solute per unit volume (liter) of water. One thousand micrograms per liter is equivalent to one milligram per liter. For concentrations less than $7,000 \mathrm{mg} / \mathrm{L}$, the numerical value is the same as for concentrations in parts per million. 


\section{Acknowledgments}

\section{Technical Reviewers}

Herbert S. Garn, Assistant District Chief, U.S. Geological Survey, Middleton, Wis.

Jeffrey A. Thornton, Principal Planner, Southeast Wisconsin Regional Planning Commission, Waukesha, Wis.

\section{Project Coordinator}

Stanley Blawas, Chairman of the Pike Lake Protection and Rehabilitation District, Hartford, Wis.

\section{Editorial and Graphics}

Michelle M. Greenwood, Cartographer, U.S. Geological Survey, Middleton, Wis.

Jennifer L. Bruce, Geographer, U.S. Geological Survey, Middleton, Wis.

James L. Kennedy, Geographer, U.S. Geological Survey, Middleton, Wis.

Jack H. Green, Hydrologist, U.S. Geological Survey, Middleton, Wis.

Chad Bloom, Student Trainee (Hydrology), U.S. Geological Survey, Middleton, Wis.

\section{Data Collection}

Daniel Olson, Hydrologic Technician, U.S. Geological Survey, Middleton, Wis.

\section{Approving Official}

Dorothy H. Tepper, Reports Improvement Advisor, U.S. Geological Survey, Reston, Va. 


\title{
Water Quality, Hydrology, and the Effects of Changes in Phosphorus Loading to Pike Lake, Washington County, Wisconsin, with Special Emphasis on Inlet-to-Outlet Short-Circuiting
}

\author{
By William J. Rose, Dale M. Robertson, and Elizabeth A. Mergener
}

\section{Abstract}

Pike Lake is a 459-acre, mesotrophic to eutrophic dimictic lake in southeastern Wisconsin. Because of concern over degrading water quality in the lake associated with further development in its watershed, a study was conducted by the U.S. Geological Survey from 1998 to 2000 to describe the water quality and hydrology of the lake, quantify sources of phosphorus including the effects of short-circuiting of inflows, and determine how changes in phosphorus loading should affect the water quality of the lake. Measuring all significant water and phosphorus sources and estimating lesser sources was the method used to construct detailed water and phosphorus budgets. The Rubicon River, ungaged near-lake surface inflow, precipitation, and ground water provide 55, 20, 17, and 7 percent of the total inflow, respectively. Water leaves the lake through the Rubicon River outlet ( 87 percent) or by evaporation (13 percent). Total input of phosphorus to the lake was about 3,500 pounds in 1999 and 2,400 pounds in 2000 . About 80 percent of the phosphorus was from the Rubicon River, about half of which came from the watershed and half from a waste-water treatment plant in Slinger, Wisconsin. Inlet-to-outlet short-circuiting of phosphorus is facilitated by a meandering segment of the Rubicon River channel through a marsh at the north end of the lake. It is estimated that 77 percent of phosphorus from the Rubicon River in monitoring year 1999 and 65 percent in monitoring year 2000 was short-circuited to the outlet without entering the main body of the lake.

Simulations using water-quality models within the Wisconsin Lake Model Suite (WiLMS) indicated Pike Lake's response to 13 different phosphorus-loading scenarios. These scenarios included a base "normal" year (2000) for which lake water quality and loading were known, six different percentage increases or decreases in phosphorus loading from controllable sources, and six different loading scenarios corresponding to specific management actions. Model simulations indicate that a 50-percent reduction in controllable loading sources would be needed to achieve a mesotrophic classification with respect to phosphorus, chlorophyll $a$, and Secchi depth (an index of water clarity). Model simulations indicated that short-circuiting of phosphorus from the inlet to the outlet was the main reason the water quality of the lake is good relative to the amount of loading from the Rubicon River and that changes in the percentage of inlet-to-outlet short-circuiting have a significant influence on the water quality of the lake.

\section{Introduction}

Pike Lake, which is located about 2 mi east of Hartford and near the metropolitan area of Milwaukee, is an important recreational water resource for Washington County, Wisconsin. The lake is the main feature of the Pike Lake Unit of the Kettle Moraine State Forest on the eastern shore of the lake (fig. 1).

Since its formation in 1983, the Pike Lake Protection and Rehabilitation District (referred to herein as the "Lake District") has promoted and implemented several measures to improve and protect the water quality of the lake. Included among these measures were the installation of a public sanitary sewerage system to serve most residential areas near the lake, and implementation of best-management practices (in cooperation with the Washington County Land Conservation Department) on agricultural lands in the watershed. In the fall of 1995, the inflow channel to the lake was plugged and a diversion channel was constructed through the marsh at the north end of the lake connecting the inflow channel with the outflow channel to enhance natural short-circuiting of high nutrient inflow to 


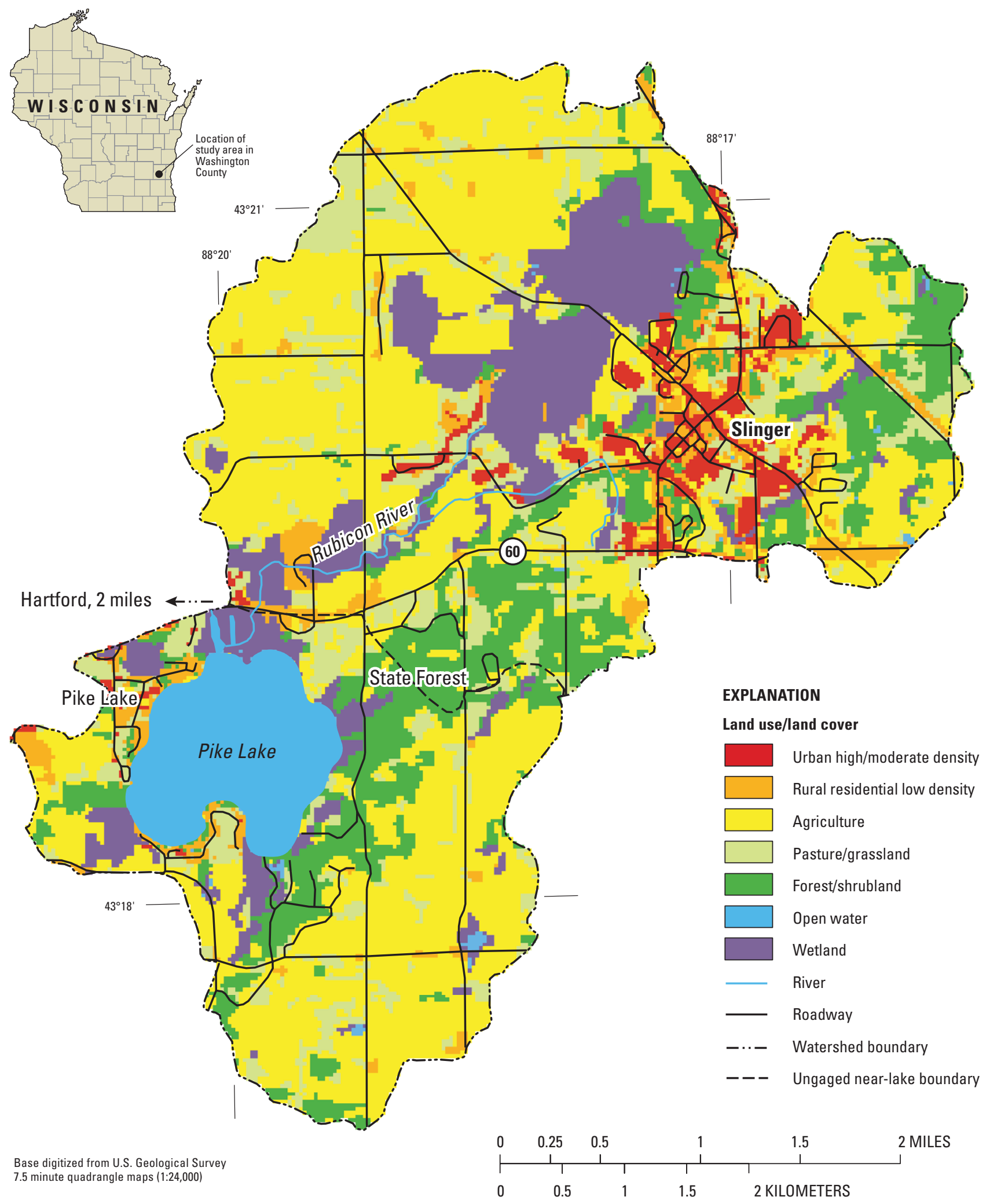

Figure 1. Drainage basin of Pike Lake, Wis. Land use/land cover from WISCLAND geographic information coverage (Lillesand and others, 1998). 
the outlet (fig. 2). However, in recent years, sediment has been deposited in the diversion channel and high flows have partially removed the plug to the original channel. Both the sedimentation in the diversion channel and the erosion of the plug may have reduced the short-circuiting efficiency (Stanley Blawas, Pike Lake Protection and Rehabilitation District, written commun., 2004).

Continuing issues of concern to lake-area residents are the effects of expanding residential and commercial development in the lake's watershed, the effects of expanding recreational use of the lake, and the influence of these changes on the water quality of the lake. In addition, there is concern that sedimentation in the dredged channel of the Rubicon River may reduce the effectiveness of the channel at directing nutrient-laden water from the inlet to the outlet of the lake.

Because of continuing concern over the perceived degradation of water quality of the lake and the need for an updated management plan for the lake, the Lake District in cooperation with the Wisconsin Department of Natural Resources (WDNR) — who provided partial funding through the Chapter NR 190 Lake Management Planning Grant program, and the U.S. Geological Survey (USGS) began on December 1, 1998 a two-year study with the following objectives:

(1) describe the water quality of the lake,

(2) define the hydrology of the lake,

(3) quantify the phosphorus sources to the lake, and

(4) assess how the water quality of the lake might respond to changes in phosphorus loading.

\section{Pike Lake and its Watershed}

Pike Lake (fig. 2) is a natural lake formed about 10,000 years ago during the Wisconsinan glaciation. A low-head dam at the lake's outlet raises the lake surface about two feet higher than if there was no dam. The lake has a surface area of 522 acres; however, if the marsh along the north side of the lake is excluded from the lake area, the remaining open-water area is 459 acres. The maximum depth of the lake is $45 \mathrm{ft}$, its volume is 6,171 acre-ft, and its mean depth is $13.5 \mathrm{ft}$ (Wisconsin Department of Natural Resources, 2001).

The major tributary to Pike Lake is the Rubicon River, which flows under State Highway 60 into the marsh at the north of the lake about 0.2 mi east of the lake's outlet (fig. 2). The area of the watershed upstream of the State Highway 60 crossing of the Rubicon River is $7.95 \mathrm{mi}^{2}$. The headwaters of the Rubicon River drain about a 1-mi marsh just northwest of Slinger (fig. 1). The river flows in a generally southwesterly direction toward Pike Lake and receives effluent from the Slinger Wastewater Treatment Plant (WWTP). Downstream from Highway 60, the river channel meanders through a marsh to where it joins the channel leaving the lake, about $0.1 \mathrm{mi}$ upstream of the dam at the lake's outlet at State Highway 60 (fig. 2). In addition to the Rubicon River watershed, the ungaged watershed directly surrounding the lake (referred to hereafter as "ungaged near-lake area") is $3.56 \mathrm{mi}^{2}$ (fig. 1).

Land use in the Pike Lake watershed is a mix of agriculture, urban (commercial, high-, and medium-density residential), rural residential, forest (much in parkland), and wetland. Land use/land cover for the Rubicon River

Table 1. Land use/land cover in the Pike Lake watershed from the WISCLAND geographic information system coverage (Lillesand and others, 1998)

\begin{tabular}{|c|c|c|c|c|c|c|}
\hline \multirow[b]{2}{*}{ Land use/land cover } & \multicolumn{2}{|c|}{$\begin{array}{c}\text { Rubicon River Watershed } \\
\text { north of Highway } 60\end{array}$} & \multicolumn{2}{|c|}{$\begin{array}{l}\text { Ungaged near-lake area } \\
\text { south of Highway } 60\end{array}$} & \multicolumn{2}{|c|}{ Entire watershed } \\
\hline & $\begin{array}{c}\text { Area } \\
\text { (acres) }\end{array}$ & $\begin{array}{c}\text { Percentage of } \\
\text { watershed }\end{array}$ & $\begin{array}{c}\text { Area } \\
\text { (acres) }\end{array}$ & $\begin{array}{c}\text { Percentage of } \\
\text { watershed }\end{array}$ & $\begin{array}{c}\text { Area } \\
\text { (acres) }\end{array}$ & $\begin{array}{c}\text { Percentage of } \\
\text { watershed }\end{array}$ \\
\hline $\begin{array}{l}\text { Urban high and moderate } \\
\text { density }\end{array}$ & 279 & 5.5 & 17 & 0.7 & 296 & 4.0 \\
\hline Rural residential & 338 & 6.6 & 115 & 5.0 & 453 & 6.1 \\
\hline Agriculture & 2,224 & 43.7 & 1,179 & 51.3 & 3,403 & 46.1 \\
\hline Pasture/grassland & 724 & 14.2 & 299 & 13.0 & 1,023 & 13.8 \\
\hline Forest & 753 & 14.8 & 420 & 18.3 & 1,173 & 15.9 \\
\hline Wetland & 765 & 15.0 & 249 & 10.8 & 1,014 & 13.7 \\
\hline Open water & 7 & 0.1 & 18 & 0.8 & 25 & 0.3 \\
\hline Total & 5,091 & 100.0 & 2,297 & 100.0 & 7,388 & 100.0 \\
\hline
\end{tabular}


watershed, the ungaged near-lake area, and the entire watershed is summarized in table 1.

\section{Purpose and Scope}

This report describes the water quality of Pike Lake, presents the water and phosphorus budgets for the lake, and gives the results of simulations to demonstrate the effects of changes in phosphorus loading on the lake's water quality. Included, also, is an assessment of the effectiveness of inlet-to-outlet short-circuiting of phosphorus by the Rubicon River.

Results of the study should be useful to the Lake District in the preparation of a comprehensive lake-management plan. In addition, the study results add to the database of available lakes for which detailed water and phosphorus loading and lake water-quality information are known.

\section{Data-Collection Methods and Sites}

Water-quality data were first collected in the lake in 1960; however, data were collected more consistently by the WDNR beginning in 1985 and by the USGS (as part of this study) in 1999. Detailed hydrologic information for the lake was not available prior to the present study. Therefore, all of the data were used to describe the water quality of the lake, but only data from December 1, 1998, to November 30, 2000 were used to describe the hydrology and phosphorus sources to the lake.

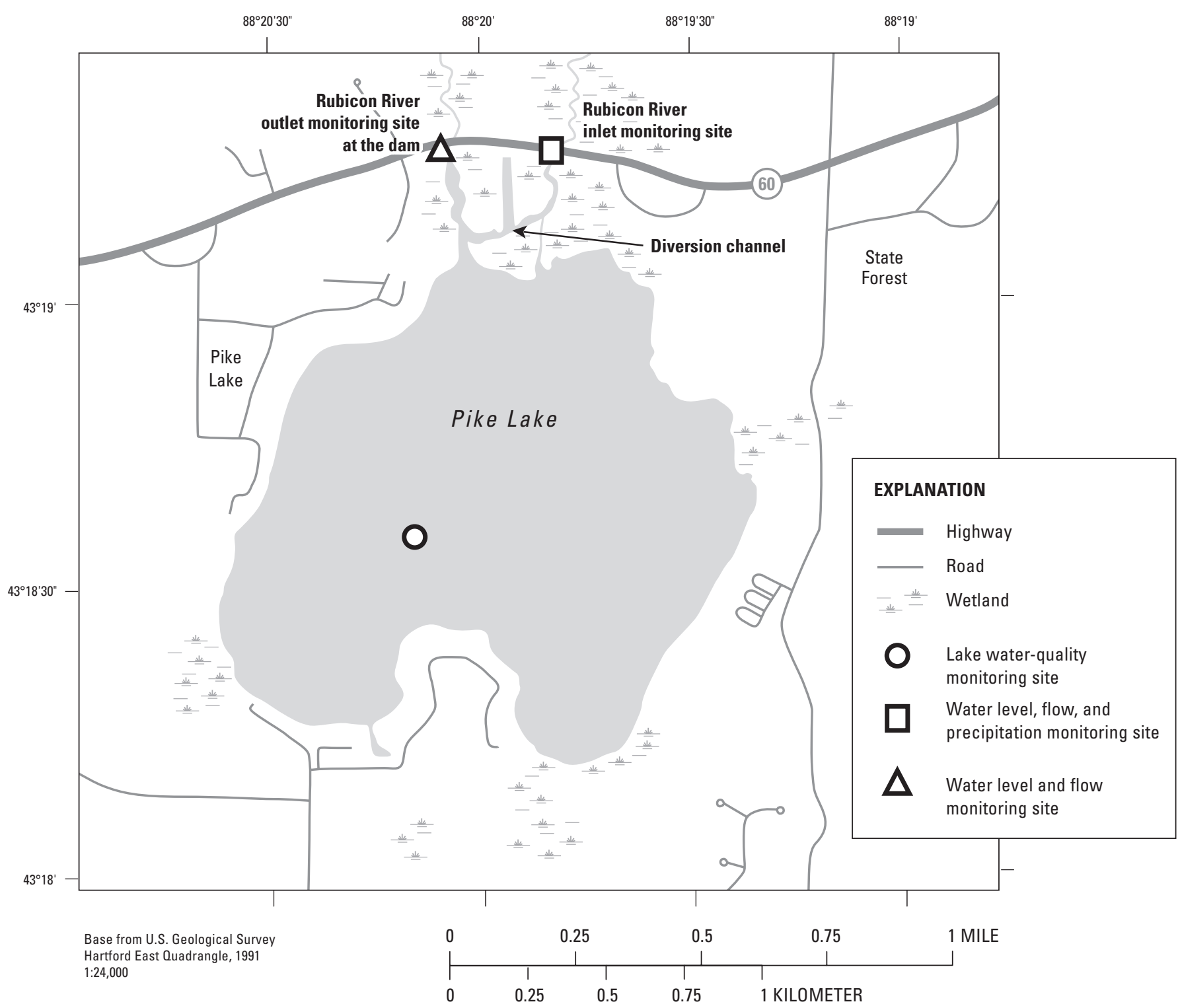

Figure 2. Locations and types of data-collection sites at or near Pike Lake, Wis. 


\section{Lake Monitoring}

Extensive water-quality data were collected in Pike Lake from 1985-99 by WDNR as part of a long-term trend-monitoring program, from 1998-2000 by the USGS as part of this study, and again in 2001 by the WDNR. During each sampling, profiles of water temperature, dissolved oxygen, specific conductance, and $\mathrm{pH}$ were collected with a multi-parameter meter, and Secchi depths (water clarity) were measured with a standard black and white Secchi disk. Near-surface samples (collected with a Van Dorn sampler by USGS, and a Kemmerer sampler by WDNR) were analyzed for total phosphorus and chlorophyll $a$ concentrations (and occasionally for various nitrogen species). Near-bottom samples (collected just above the sediment/water interface with a Van Dorn sampler) were analyzed for total phosphorus concentration. In addition, water samples were occasionally (usually during spring or fall turnover) analyzed for common ions and other characteristics, such as color, turbidity, and total dissolved solids.

One method of classifying the water quality of a lake is by computing water-quality or trophic state index (TSI) values based on near-surface total phosphorus and chlorophyll $a$ concentrations, and Secchi depths, as developed by Carlson (1977) and modified for Wisconsin lakes by Lillie and others (1993). The indices were developed to place these three characteristics on similar scales to allow comparison of different lakes. TSI values based on phosphorus concentrations $\left(\mathrm{TSI}_{\mathrm{P}}\right)$, chlorophyll $a$ concentrations $\left(\mathrm{TSI}_{\mathrm{C}}\right)$, and Secchi depths $\left(\mathrm{TSI}_{\mathrm{SD}}\right.$ ) were computed for each sampling by use of equations $1-3$. These values were averaged to compute summer (June through September) average TSI values:

$$
\begin{aligned}
& \mathrm{TSI}_{\mathrm{p}}=28.24+17.81\left[\log _{10}\right. \text { phosphorus } \\
& \quad \text { (in milligrams per liter x 1000) }] \\
& \mathrm{TSI}_{\mathrm{C}}=34.82+17.41\left[\log _{10} \text { chlorophyll } a\right. \\
& \quad \text { (in micrograms per liter) }]
\end{aligned}
$$

$$
\mathrm{TSI}_{\mathrm{SD}}=77.13-33.2\left[\log _{10}\right. \text { Secchi depth }
$$
(in feet)]

Oligotrophic lakes (TSI values less than 40) have a limited supply of nutrients, typically are clear, have low algal populations and low phosphorus concentrations, and typically contain oxygen throughout the year in their deepest zones (Wisconsin Department of Natural Resources, 1992). Mesotrophic lakes (TSI values between 40 and 50) have a moderate supply of nutrients, moderate clarity, and are prone to moderate algal blooms; occasional oxygen depletions in the deepest zones of the lake are possible.
Eutrophic lakes (TSI values greater than 50) are nutrientrich with corresponding water-quality problems, such as frequent seasonal algal blooms; oxygen depletion is common in the deeper zones of the lake, and clarity typically is poor.

\section{Stream Monitoring}

Stream monitoring was intensively conducted at the Rubicon River inlet to Pike Lake at State Highway 60 and the Rubicon River outlet from the lake at State Highway 60 (fig. 2). Data from these sites were published in the USGS Annual Data Report series (Waschbusch and others, 2001).

Both sites required considerable hydraulic analyses to determine discharge. Neither site was suited to conventional means of discharge monitoring, in which stage is monitored and discharge is determined through the use of stage-discharge relations. At the inlet, very small watersurface gradients precluded the development of a stagedischarge relation. At the outlet site, two lift gates regulate discharge from the lake. These gates were frequently adjusted, precluding development of a simple stage-discharge relation.

At the inlet site, stream stage was recorded at 15minute intervals. Flow was calculated using the Manning equation (King and Brater, 1963). The equation written in terms of discharge is

$$
\mathrm{Q}=(1.486 / \mathrm{n}) \mathrm{AR}^{2 / 3} \mathrm{~S}^{1 / 2},
$$

where

$\mathrm{Q}=$ discharge $\left(\mathrm{ft}^{3} / \mathrm{s}\right)$,

$\mathrm{A}=$ cross-sectional area $\left(\mathrm{ft}^{2}\right)$,

$\mathrm{R}=$ hydraulic radius $(\mathrm{ft})$,

$\mathrm{S}=$ friction slope, and

$\mathrm{n}=$ roughness coefficient.

In the Manning equation, (1.846/n) $\left.\mathrm{AR}^{2 / 3}\right)$ is referred to as conveyance $(\mathrm{K})$; therefore, the Manning equation can be expressed as

$$
\mathrm{Q}=\mathrm{KS}^{1 / 2}
$$

For this study, slope ( $\mathrm{S}$ ) was calculated as the difference in stage at the inlet gage at Highway 60 and the lake stage divided by the channel length between Highway 60 and the lake. Numerous (54) measurements of discharge were made over a wide range of discharges during the 2-year study. Conveyance (K) was calculated for each discharge measurement using measured $\mathrm{Q}$ and corresponding $\mathrm{S}$ values. From these data, an equation expressing $\mathrm{K}$ as a function of stream stage was determined. Discharge was 
calculated at hourly intervals using equation 5. Daily average discharge was determined as the average of the hourly discharges during each day.

The Rubicon River at the outlet of the lake was equipped with instruments to monitor stage upstream and downstream of the dam, and the positions of each of the two gates in the dam. These measurements were made at 15-minute intervals. In addition, the Pike Lake Advancement Association which operates the dam, provided manual measurements of upstream stages and gate openings. Flow out of the lake through the gates was calculated using the monitored data and the orifice-flow equation (King and Brater, 1963)

$$
\mathrm{Q}=\mathrm{AC}(2 \mathrm{gH})^{1 / 2},
$$

where

$$
\begin{aligned}
& \mathrm{Q}=\text { discharge }\left(\mathrm{ft}^{3} / \mathrm{s}\right), \\
& \mathrm{A}=\text { area of gate opening }\left(\mathrm{ft}^{2}\right), \\
& \mathrm{C}=\text { a coefficient } \\
& \mathrm{g}=\text { acceleration of gravity }\left(\mathrm{ft} / \mathrm{s}^{2}\right), \text { and } \\
& \mathrm{H}=\text { difference in stage upstream and downstream of } \\
& \quad \text { the gate }(\mathrm{ft}) .
\end{aligned}
$$

The coefficient $\mathrm{C}$ was determined to be 0.7 by solving equation 6 for $\mathrm{C}$ when all other variables were known. About fifty measurements of $\mathrm{Q}$ were made during the 2year study. Flows for each of the two gates were calculated using equation 6 and summed to get total flow.

Water was sampled by three different methods for determination of phosphorus concentration. An automatic water sampler collected samples at the Rubicon River inlet to the lake. Additional samples were collected manually by the "grab" (dipped bottle) method or by the equal-widthincrement (EWI) method (Edwards and Glysson, 1999). The Rubicon River at the lake outlet site was sampled by either the EWI or grab methods.
All lake and stream samples were analyzed by the Wisconsin State Laboratory of Hygiene in accordance with standard analytical procedures described in the "Manual of Analytical Methods, Inorganic Chemistry Unit" (Wisconsin State Laboratory of Hygiene, 1993).

\section{Water Quality of Pike Lake}

Pike Lake is a dimictic lake, meaning that the lake thermally stratifies throughout summer and under the ice during winter. During summer, a thermocline (the depth range where there is a rapid temperature change) develops in early June and stays well established through September. The thermocline usually develops 12 to $20 \mathrm{ft}$ from the surface. Bottom temperatures usually are about $10^{\circ} \mathrm{C}$, and change little throughout summer. Dissolved oxygen concentrations are near saturation throughout the lake just after the ice melts, but oxygen is quickly depleted below the thermocline by mid-June. Throughout most of summer, dissolved oxygen concentrations are near zero below the thermocline. During late fall, the lake completely mixes and dissolved oxygen concentrations at all depths are near saturation. Reverse thermal stratification develops under the ice, with bottom temperatures warming to near $5^{\circ} \mathrm{C}$ by late winter while temperatures just beneath the ice remain near $0^{\circ} \mathrm{C}$. Dissolved oxygen concentrations usually decrease as winter progresses but usually remain above $5 \mathrm{mg} / \mathrm{L}$ except in the bottom few feet of the lake. The specific conductance throughout the lake at spring and fall overturns and near the surface during other periods is about $600 \mu \mathrm{S} \mathrm{cm}^{-1}$, but increases to over $700 \mu \mathrm{S} \mathrm{cm}^{-1}$ near the bottom of the lake during late summer and late winter. The $\mathrm{pH}$ in the upper part of the lake is typically near or

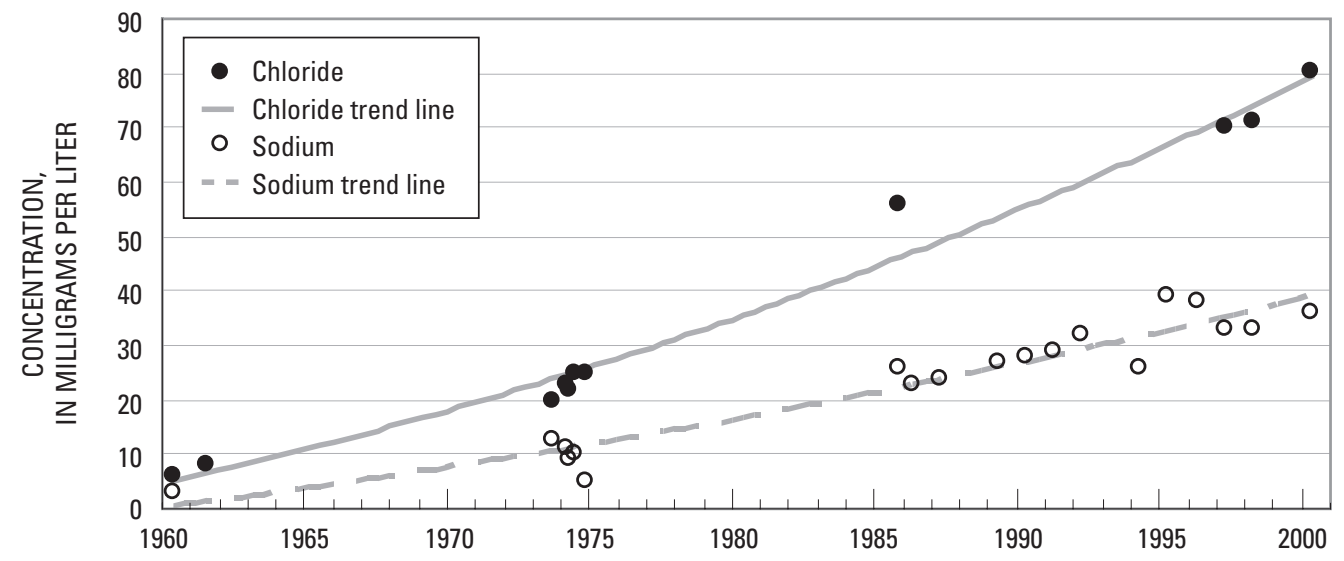

Figure 3. Trends in chloride and sodium concentrations in Pike Lake near Hartford, Wis.,1960-2000. 
Table 2. Average summer (June through September) water quality and trophic state index (TSI) values for Pike Lake [ft, feet; mg/L, milligrams per liter; $\mu \mathrm{g} / \mathrm{L}$, micrograms per liter; --, not available]

\begin{tabular}{|c|c|c|c|c|c|c|}
\hline \multirow{2}{*}{ Year } & \multicolumn{2}{|c|}{ Secchi depth } & \multicolumn{2}{|c|}{ Total phosphorus } & \multicolumn{2}{|c|}{ Chlorophyll a } \\
\hline & (ft) & TSI & (mg/L) & TSI & $(\mu \mathrm{g} / \mathrm{L})$ & TSI \\
\hline 1973 & 5.5 & 52.6 & 0.030 & 54.5 & -- & -- \\
\hline 1974 & 8.0 & 47.1 & .030 & 54.5 & -- & -- \\
\hline 1980 & 7.2 & 48.6 & -- & -- & 4.0 & 45.3 \\
\hline 1981 & -- & -- & -- & -- & 8.9 & 51.3 \\
\hline 1985 & 4.4 & 55.9 & .022 & 52.0 & 11.5 & 53.3 \\
\hline 1986 & 5.0 & 55.6 & .020 & 51.4 & 9.6 & 51.2 \\
\hline 1987 & 9.9 & 45.7 & .020 & 51.0 & 9.5 & 51.4 \\
\hline 1988 & 6.8 & 50.6 & .030 & 54.0 & 6.7 & 48.6 \\
\hline 1989 & 6.7 & 50.1 & .017 & 49.9 & 10.0 & 51.7 \\
\hline 1990 & 7.3 & 49.5 & .018 & 50.4 & 8.3 & 49.6 \\
\hline 1991 & 5.2 & 53.4 & .019 & 50.8 & 7.3 & 49.7 \\
\hline 1992 & 10.1 & 45.1 & .017 & 50.3 & 6.3 & 47.8 \\
\hline 1993 & 9.5 & 47.5 & .026 & 53.0 & 11.6 & 51.3 \\
\hline 1994 & 6.1 & 52.7 & .027 & 53.7 & 12.9 & 54.1 \\
\hline 1995 & 5.2 & 53.4 & .022 & 52.0 & 6.9 & 48.4 \\
\hline 1996 & 6.5 & 50.6 & .020 & 50.9 & 7.8 & 49.6 \\
\hline 1997 & 6.0 & 51.5 & .022 & 51.8 & 8.4 & 49.9 \\
\hline 1998 & 4.8 & 54.5 & .020 & 51.4 & 4.8 & 46.4 \\
\hline 1999 & 7.9 & 47.4 & .019 & 50.7 & 5.5 & 47.7 \\
\hline 2000 & 5.4 & 53.2 & .023 & 52.2 & 7.0 & 49.4 \\
\hline 2001 & 3.6 & 58.6 & .023 & 52.5 & 8.0 & 50.5 \\
\hline Average & 6.6 & 51.2 & .022 & 52.0 & 8.2 & 49.9 \\
\hline
\end{tabular}

slightly above 8 ( $\mathrm{pH}$ values are in standard units), and near 7 in the deeper water.

The chemical character of water in Pike Lake is fairly typical of water in southeastern Wisconsin lakes, reflecting the limestone and dolomite in the glacial deposits and bedrock. According to Lillie and Mason (1983), high concentrations of calcium, magnesium, and alkalinity characterize lakes in this region. They found that for about 60 lakes in their study, average concentrations for calcium, magnesium, and alkalinity were 36, 32, and $173 \mathrm{mg} / \mathrm{L}$, respectively. During this study, average concentrations for calcium, magnesium, and alkalinity in Pike Lake were 44, 35 , and $210 \mathrm{mg} / \mathrm{L}$, respectively.

Chloride and sodium concentrations in Pike Lake have increased steadily since 1960 . Concentrations of chloride have increased from $6.1 \mathrm{mg} / \mathrm{L}$ in 1960 to 80.1 $\mathrm{mg} / \mathrm{L}$ in 2000 (more than 10-fold)(fig. 3). Concentrations of sodium have increased from about $3 \mathrm{mg} / \mathrm{L}$ in 1960 to about $40 \mathrm{mg} / \mathrm{L}$ in 2000 (fig. 3). Increasing use of salt for deicing roads combined with increasing use of salt-based water softeners is likely to be the cause of this increase in Pike Lake and other lakes in southeastern Wisconsin. The median concentration of chloride in 16 southeastern Wisconsin lakes sampled by the USGS in 2001 was $39 \mathrm{mg} / \mathrm{L}$, and the maximum observed concentration in those lakes was $120 \mathrm{mg} / \mathrm{L}$ (U.S. Geological Survey, Wisconsin District Lake-Studies Team, 2001). For comparison, chloride concentration in seawater is about $19,000 \mathrm{mg} / \mathrm{L}$ (Hem, 1985).

The summer-average (June through September) water clarity in Pike Lake, as measured with a Secchi disk, was $6.6 \mathrm{ft}$, but it has ranged from about $4 \mathrm{ft}$ in 1985 and 2001 to about $10 \mathrm{ft}$ in 1992 (table 2 and fig. 4). Individual measurements have ranged from about $2.5 \mathrm{ft}$ in 1986 to $14 \mathrm{ft}$ in 1992. During 2000, the summer-average Secchi depth was $5.4 \mathrm{ft}$ (table 2). Secchi depths less than $6 \mathrm{ft}$ indicate eutrophic conditions. Therefore, average Secchi depths in Pike Lake indicate the lake typically is on the border between mesotrophic and eutrophic. 


\section{Secchi depth}

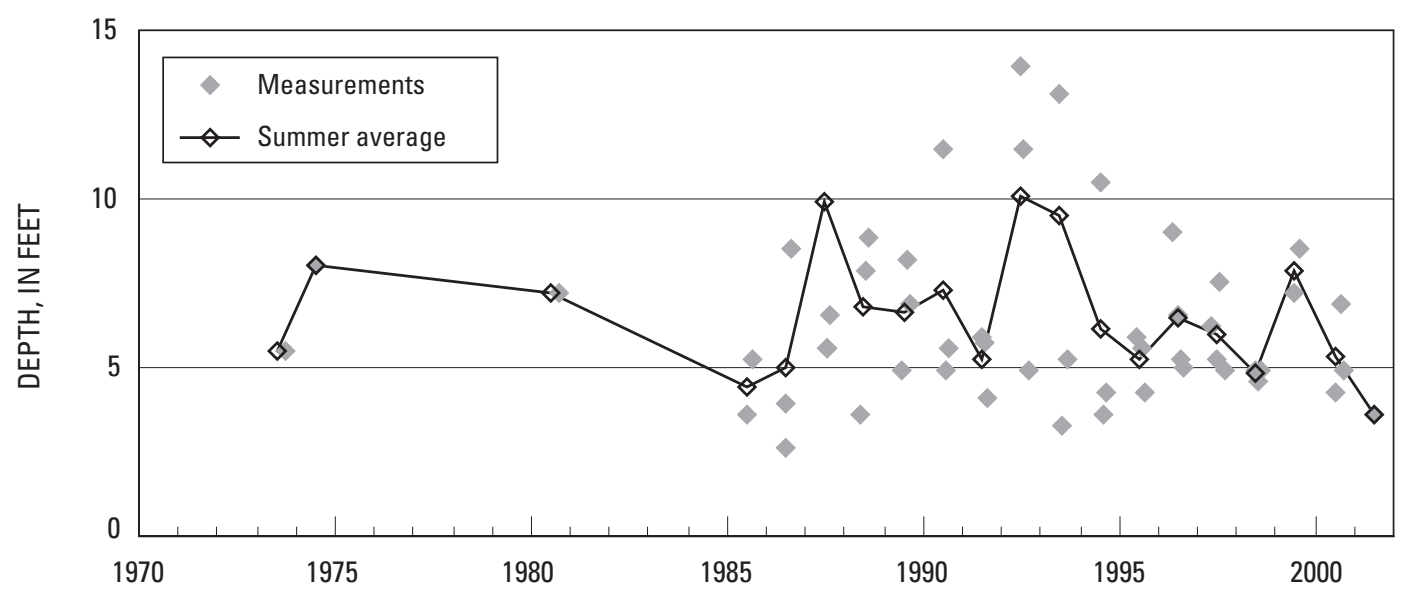

Total phosphorus

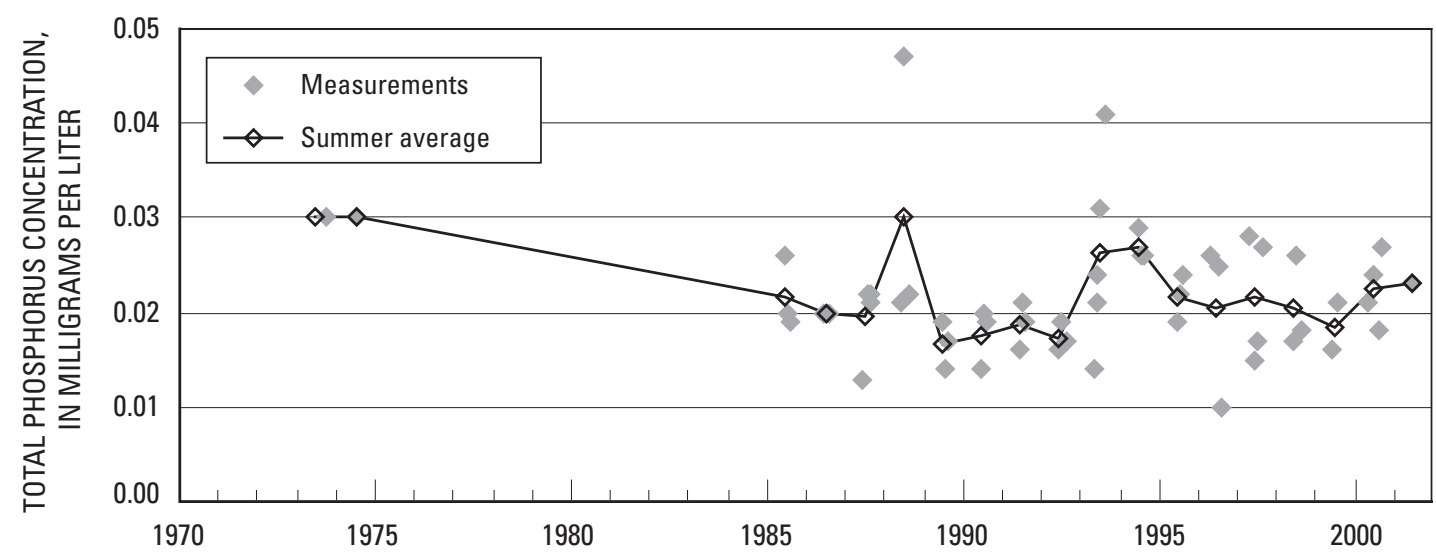

Chloroph II a

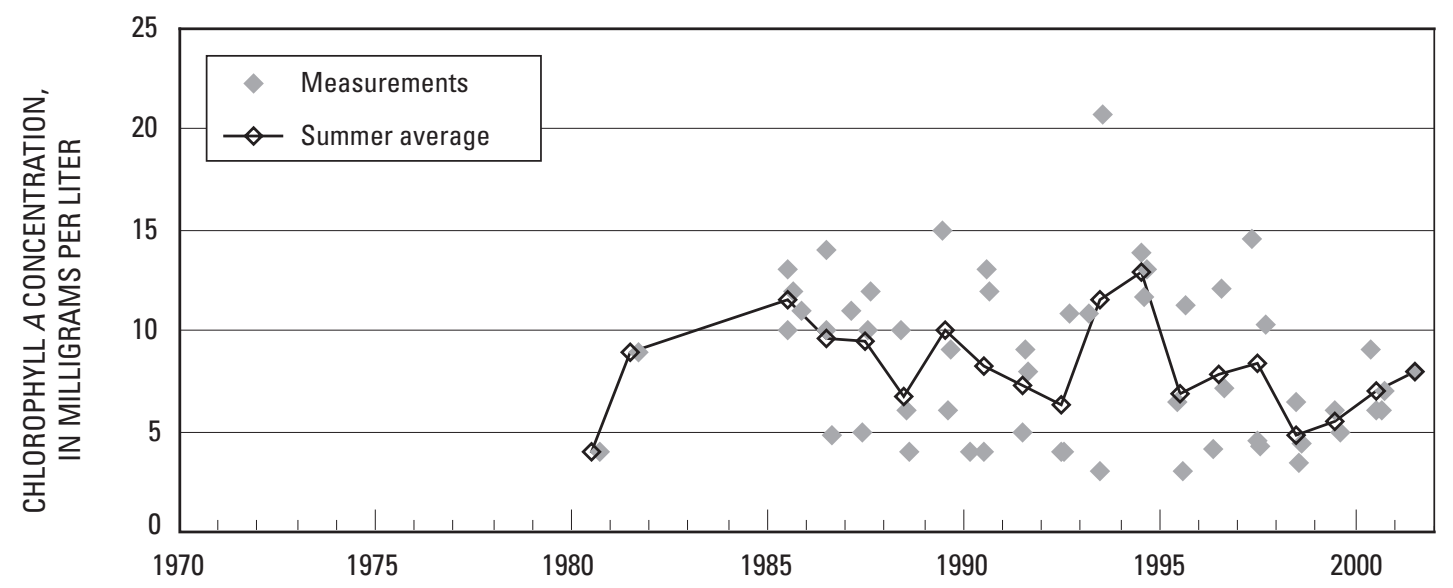

Figure 4. Measured Secchi depths, and total phosphorus and chlorophyll a concentrations, and summer (June through September) average values at the deep hole in Pike Lake near Hartford, Wis., 1973-2001. 


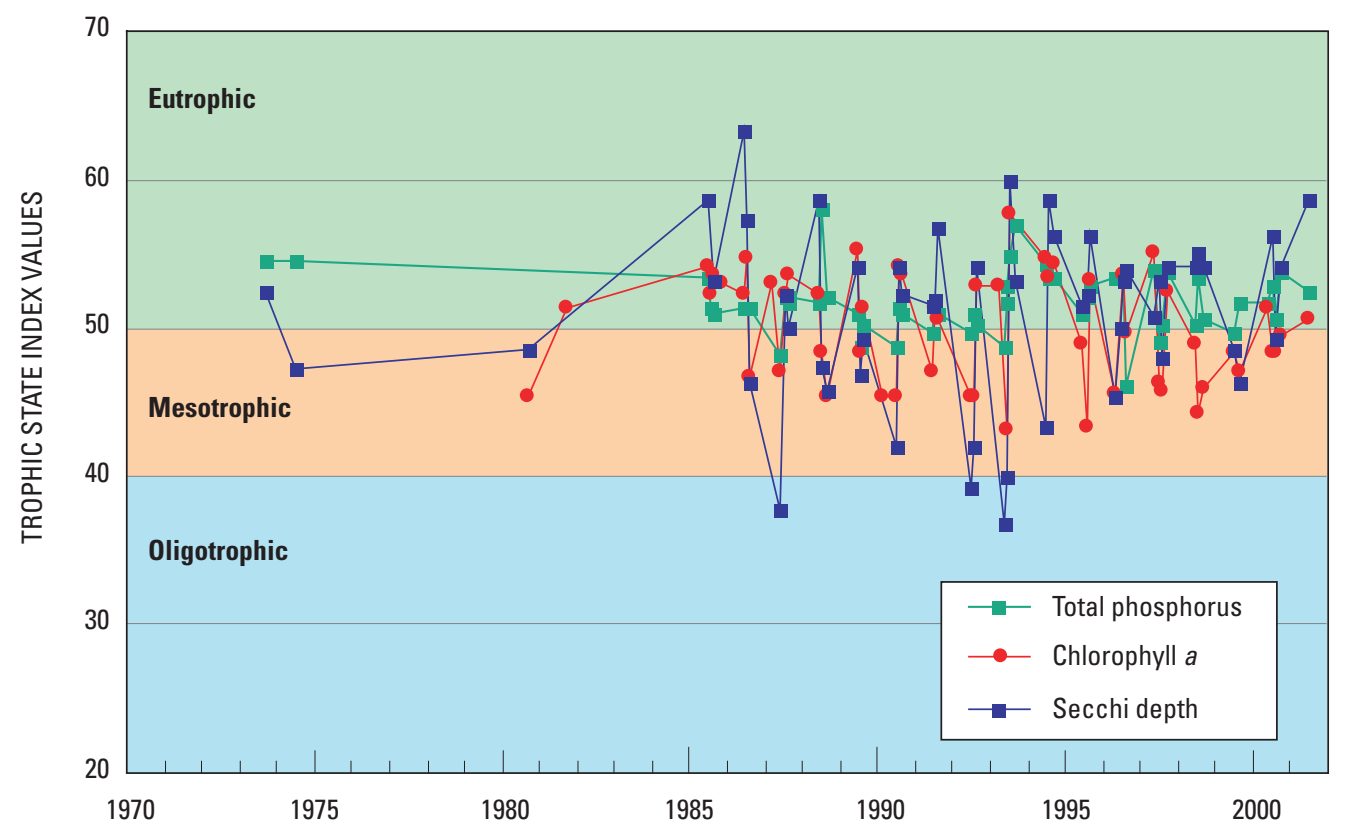

Figure 5. Trophic state index (TSI) values based on surface concentrations of total phosphorus and chlorophyll a, and Secchi depths for Pike Lake, near Hartford, Wis., 1973-2002.

Phosphorus and nitrogen are essential nutrients for plant growth and are the nutrients that usually limit algal growth in Midwestern lakes. High nutrient concentrations can cause high algal populations (blooms) and can therefore be the cause of eutrophication (that is, aging and increased productivity) of lakes. Near-surface total phosphorus concentrations greater than about 0.017 to 0.020 $\mathrm{mg} / \mathrm{L}$ indicate eutrophic conditions. Near-surface total phosphorus concentrations in Pike Lake have ranged from 0.010 to $0.047 \mathrm{mg} / \mathrm{L}$ (fig. 4). Summer-average or growingseason (May through September) near-surface phosphorus concentrations have fluctuated from about $0.018 \mathrm{mg} / \mathrm{L}$ from 1989 to 1992 to over $0.025 \mathrm{mg} / \mathrm{L}$ in 1988,1993 , and 1994 (table 2). Phosphorus concentrations decreased after 1994. During 2000, the year with the most extensive water-quality data collected during this study, the summeraverage near-surface total phosphorus concentration was $0.0225 \mathrm{mg} / \mathrm{L}$ (table 2), the average annual concentration was $0.022 \mathrm{mg} / \mathrm{L}$, and the concentration during spring overturn was $0.021 \mathrm{mg} / \mathrm{L}$. Therefore, the summer-average total phosphorus concentrations have indicated the lake typically is on the border between mesotrophic and eutrophic.

Near-bottom phosphorus concentrations increase dramatically after the onset of anoxic conditions, which indicate a release of phosphorus from the lake sediments. Near-bottom concentrations have been measured as high as $0.600 \mathrm{mg} / \mathrm{L}$ on several occasions.
Near-surface total nitrogen concentrations (computed as the sum of Kjeldahl nitrogen and dissolved nitrite plus nitrate) ranged from 0.79 to $1.36 \mathrm{mg} / \mathrm{L}$ during the summers of 2000 and 2001.

The ratio of the concentration of total nitrogen to total phosphorus (N:P ratio) is often used to determine the potential limiting nutrient in a lake. The specific value of this ratio that determines which nutrient potentially is limiting differs under different conditions such as water temperature, light intensity, and nutrient deficiencies (Correll, 1998); however, a ratio greater than about 16:1 by weight usually indicates that phosphorus should be the potentially limiting nutrient. Data for total nitrogen and total phosphorus were available only from 1973 to 1975. The N:P ratio for these years ranged from 18:1 to 51:1. Therefore, phosphorus typically should have been the nutrient limiting algal growth in Pike Lake (and probably continues to limit algal growth) and is the nutrient to focus on when considering management efforts to improve water quality.

Chlorophyll $a$ is a photosynthetic pigment found in algae and other green plants. Its concentration commonly is used as a measure of the density of the algal population in a lake. Concentrations greater than about 7-10 $\mu \mathrm{g} / \mathrm{L}$ indicate eutrophic conditions and greater than $20-30 \mu \mathrm{g} / \mathrm{L}$ usually are associated with algal blooms. During the study period, near-surface chlorophyll $a$ concentrations ranged from 3 to $21 \mu \mathrm{g} / \mathrm{L}$ (fig. 4), with an overall summer-average 
concentration of about $8 \mu \mathrm{g} / \mathrm{L}$ (table 2). The summer-average concentrations ranged from $4 \mu \mathrm{g} / \mathrm{L}$ in 1980 to $13 \mu \mathrm{g} / \mathrm{L}$ in 1994. Chlorophyll $a$ concentrations decreased after 1994. The summer-average concentration in 2000 was 7 $\mu \mathrm{g} / \mathrm{L}$. Therefore, summer-average chlorophyll concentrations indicate the lake typically is on the border between mesotrophic and eutrophic and only occasionally experiences extensive algal blooms.

All three trophic state indices, based on near-surface concentrations of total phosphorus and chlorophyll $a$, and on Secchi depth, indicate Pike Lake ranges between mesotrophic and eutrophic (fig. 5). However, better water clarity in the early part of summer (May and June) occasionally results in the lake being classified as oligotrophic, but usually the periods of very good water clarity are short lived.

The water quality of Pike Lake has fluctuated during the period of record (1974 to 2001); however, no significant long-term changes were observed in any parameter related to the trophic status of the lake. Concentrations of total phosphorus and chlorophyll $a$ may have improved slightly since 1994 . This improvement possibly was due to increased sanitary sewerage service and to the redredging of the diversion channel to improve inlet-to-outlet shortcircuiting of nutrients. Moderate changes in sodium and chloride, however, were similar to those observed for many other lakes in Wisconsin in recent years.

\section{Hydrology of Pike Lake}

Because productivity in Pike Lake is limited by the input of phosphorus (based on $\mathrm{N}: \mathrm{P}$ ratios), reduction in phosphorus input to the lake would improve water quality. Most of the phosphorus entering the lake is transported by water inputs. Therefore, to quantify phosphorus inputs, it is necessary to quantify water inputs. Water budgets for the lake were quantified for the two monitoring years from December 1998 through November 1999 (hereafter referred to as MY1999) and December 1999 through November 2000 (hereafter referred to as MY2000).

The hydrology of Pike Lake can be described in terms of components of its water budget. The water budget for a period of interest may be represented by the equation

$$
\Delta \mathrm{S}=\left(\mathrm{PPT}+\mathrm{SW}_{\mathrm{In}}+\mathrm{GW}_{\mathrm{In}}\right)-\left(\text { Evap }+\mathrm{SW}_{\text {Out }}+\mathrm{GW}_{\text {Out }}\right),
$$

where $\Delta \mathrm{S}$ is the change in the volume of water stored in the lake and is equal to the sum of the volumes of water entering the lake minus the sum of the volumes of water leaving the lake. Water enters the lake as precipitation (PPT), surface-water inflow $\left(\mathrm{SW}_{\mathrm{In}}\right)$, and ground-water inflow $\left(\mathrm{GW}_{\mathrm{In}}\right)$. Water leaves the lake through evaporation (Evap), surface-water outflow $\left(\mathrm{SW}_{\text {Out }}\right)$, and ground-water outflow $\left(\mathrm{GW}_{\text {Out }}\right)$. Each term of the water budget was computed on a daily basis.

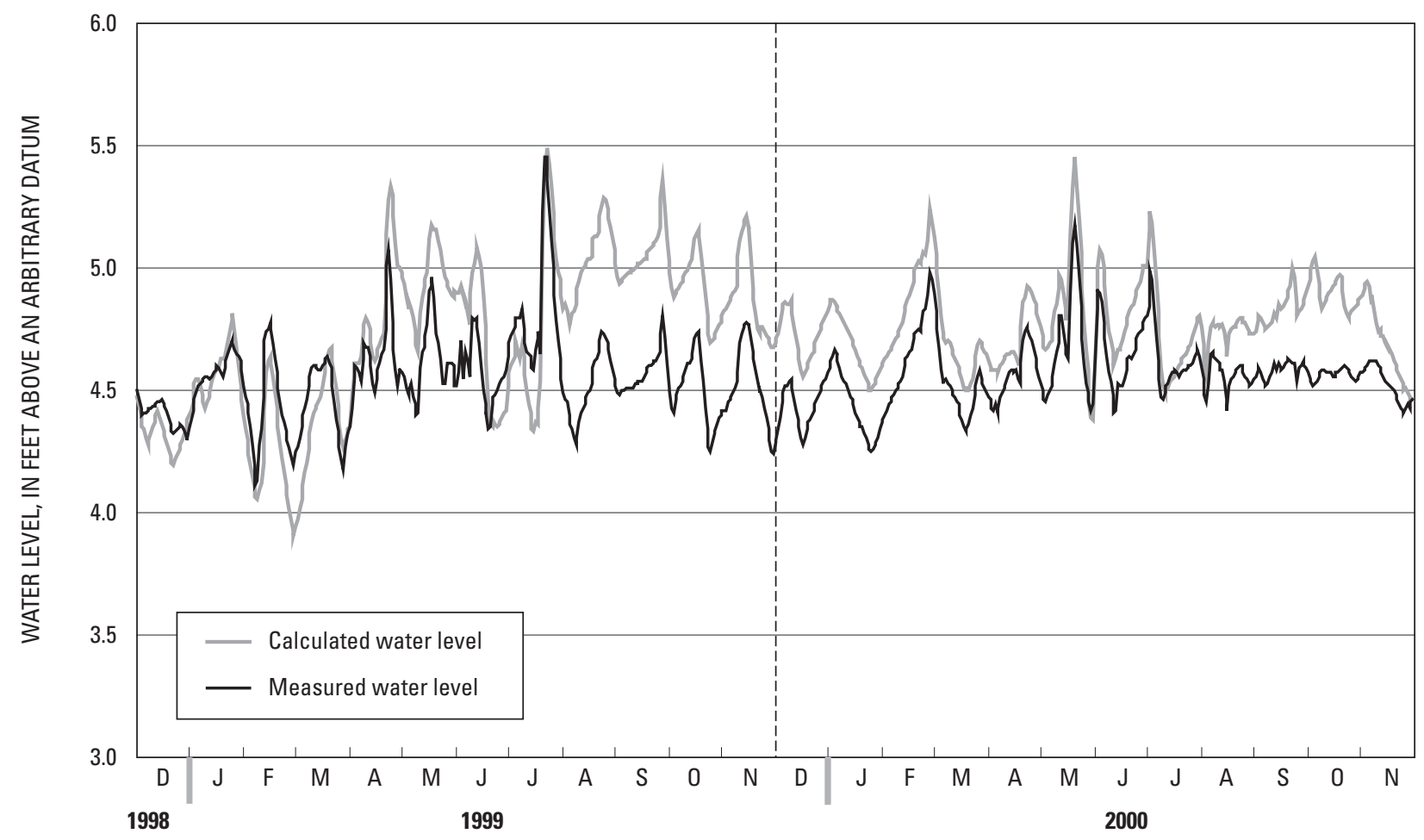

Figure 6. Measured and calculated daily water levels of Pike Lake near Hartford, Wis., December 1998-November 2000. Dashed line separates monitoring years 1999 and 2000. 


\section{Change in Storage}

Changes in the volume of the lake were determined from water elevations measured every 15 minutes at the outlet just upstream of the dam (fig. 2). Lake stage fluctuated from a minimum $4.11 \mathrm{ft}$ (relative to an arbitrary datum) to a maximum altitude of $5.45 \mathrm{ft}$ (figure 6). For the sake of simplifying calculations, the area of the lake was assumed to be constant over the relatively small $(1.34 \mathrm{ft})$ range in stage during the study.

\section{Precipitation}

During the 2-year study, total daily precipitation was measured at the Rubicon River inlet monitoring site during nonfreezing periods. During freezing periods, precipitation was estimated from measurements by the National Weather Service observer at Hartford, about 2 mi east of the lake. Precipitation on the lake surface during MY1999, was 40.04 in. (1,615 acre-ft) and during MY2000 was 34.01 in. (1,372 acre-ft) (table 3). Precipitation was 8.3 in. greater than the long-term (1961-90) average for Hartford during 1999, and was 2.27 in. greater than average in 2000 . Monthly precipitation during each monitoring year is compared to average monthly precipitation during 1961-90 in figure 7 .

\section{Surface-Water Inflow}

Daily inflow data at the Rubicon River inlet to the lake (fig. 8) were used to estimate the total surface inflow to the lake. These data represented the combined runoff from the watershed upstream of Highway 60 and discharge from the Slinger WWTP. The maximum instantaneous flow at the Rubicon River at Highway 60 was $138 \mathrm{ft}^{3} / \mathrm{s}$ on July 21, 1999. In MY1999, 5,296 acre-ft of water passed the monitoring site, with 762 acre-ft provided by Slinger's WWTP, and in MY2000, 4,148 acre-ft passed the monitoring site, with 665 acre-ft provided by Slinger's WWTP (G. D. Moser, Slinger Wastewater Treatment Plant, written commun., 2002; table 3).

The ungaged near-lake area downstream from Highway 60 provides runoff to the lake in addition to that monitored at the inlet. This ungaged runoff was assumed to be contributed at a rate per unit area similar to the watershed upstream of the inlet. Daily flow from this ungaged area was estimated to be equal to the daily flow at the inlet at Highway 60 minus the daily flow from the Slinger WWTP times the ratio of the ungaged area to the area upstream of Highway 60. Ungaged runoff from the near-lake area downstream of Highway 60 contributed 2,029 acre-ft in MY1999 and 1,559 acre-ft in MY2000 (table 3).

Based on the above-normal precipitation, runoff in the Rubicon River would be expected to be greater than normal for both years of the study, but especially in MY1999.

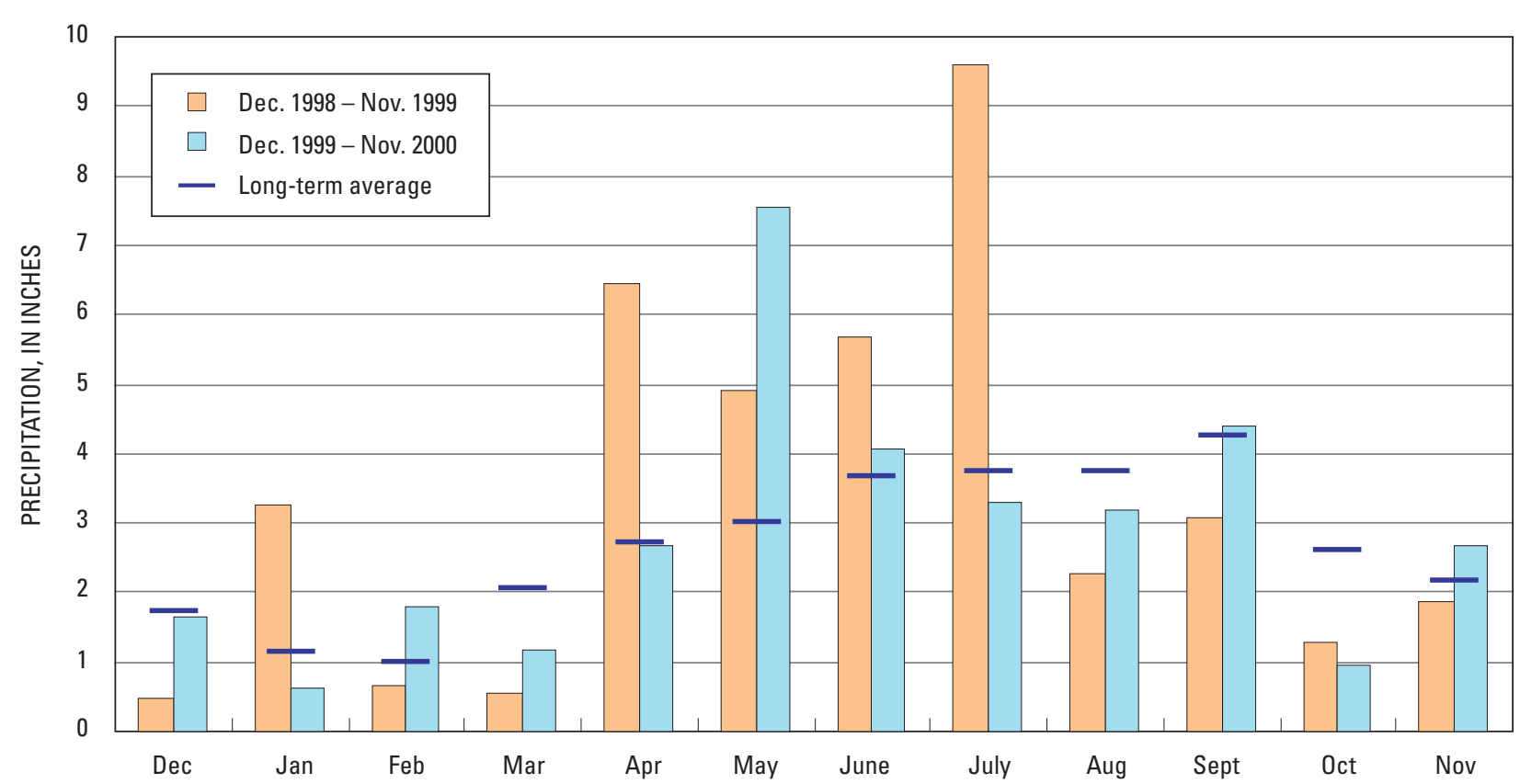

Figure 7. Precipitation at Pike Lake, Wis., during December 1998-November 2000 relative to long-term average precipitation at Hartford, Wis. 
Table 3. Water budget for Pike Lake near Hartford, Wis., monitoring years 1999 and 2000

[Monitoring year, December-November; MY, monitoring year; all data in acre-feet or percentage of total; WWTP, waste-water treatment plant]

\begin{tabular}{|c|c|c|c|c|c|c|}
\hline Budget component & MY1999 & $\begin{array}{c}\text { MY1999 } \\
\text { (percent) }\end{array}$ & MY2000 & $\begin{array}{l}\text { MY2000 } \\
\text { (percent) }\end{array}$ & $\begin{array}{c}\text { Two-year } \\
\text { average }\end{array}$ & $\begin{array}{c}\text { Two-year } \\
\text { average (percent) }\end{array}$ \\
\hline \multicolumn{7}{|c|}{ Inputs to lake } \\
\hline Precipitation & 1,615 & 16.9 & 1,372 & 17.8 & 1,493 & 17.3 \\
\hline Rubicon River (inlet) & 5,296 & 55.4 & 4,148 & 53.9 & 4,722 & 54.7 \\
\hline Slinger WWTP & 762 & 8.0 & 665 & 8.6 & 713 & 8.3 \\
\hline Rubicon River minus WWTP & 4,534 & 47.4 & 3,483 & 45.2 & 4,009 & 46.4 \\
\hline Ungaged near-lake area & 2,029 & 21.2 & 1,559 & 20.2 & 1,794 & 20.8 \\
\hline Ground water ${ }^{1}$ & 620 & 6.5 & 622 & 8.1 & 621 & 7.2 \\
\hline Total input & 9,560 & 100.0 & 7,701 & 100.0 & 8,631 & 100.0 \\
\hline \multicolumn{7}{|c|}{ Outputs from lake } \\
\hline Evaporation & 1,134 & 12.0 & 1,134 & 14.6 & 1,134 & 13.2 \\
\hline Rubicon River (outlet) & 8,312 & 88.0 & 6,652 & 85.4 & 7,482 & 86.8 \\
\hline Ground water ${ }^{1}$ & 0 & 0.0 & 0 & 0.0 & 0 & 0.0 \\
\hline Total output & 9,446 & 100.0 & $\mathbf{7 , 7 8 6}$ & 100.0 & 8,616 & 100.0 \\
\hline
\end{tabular}

${ }^{1}$ It was assumed that there was no ground-water recharge from the lake.
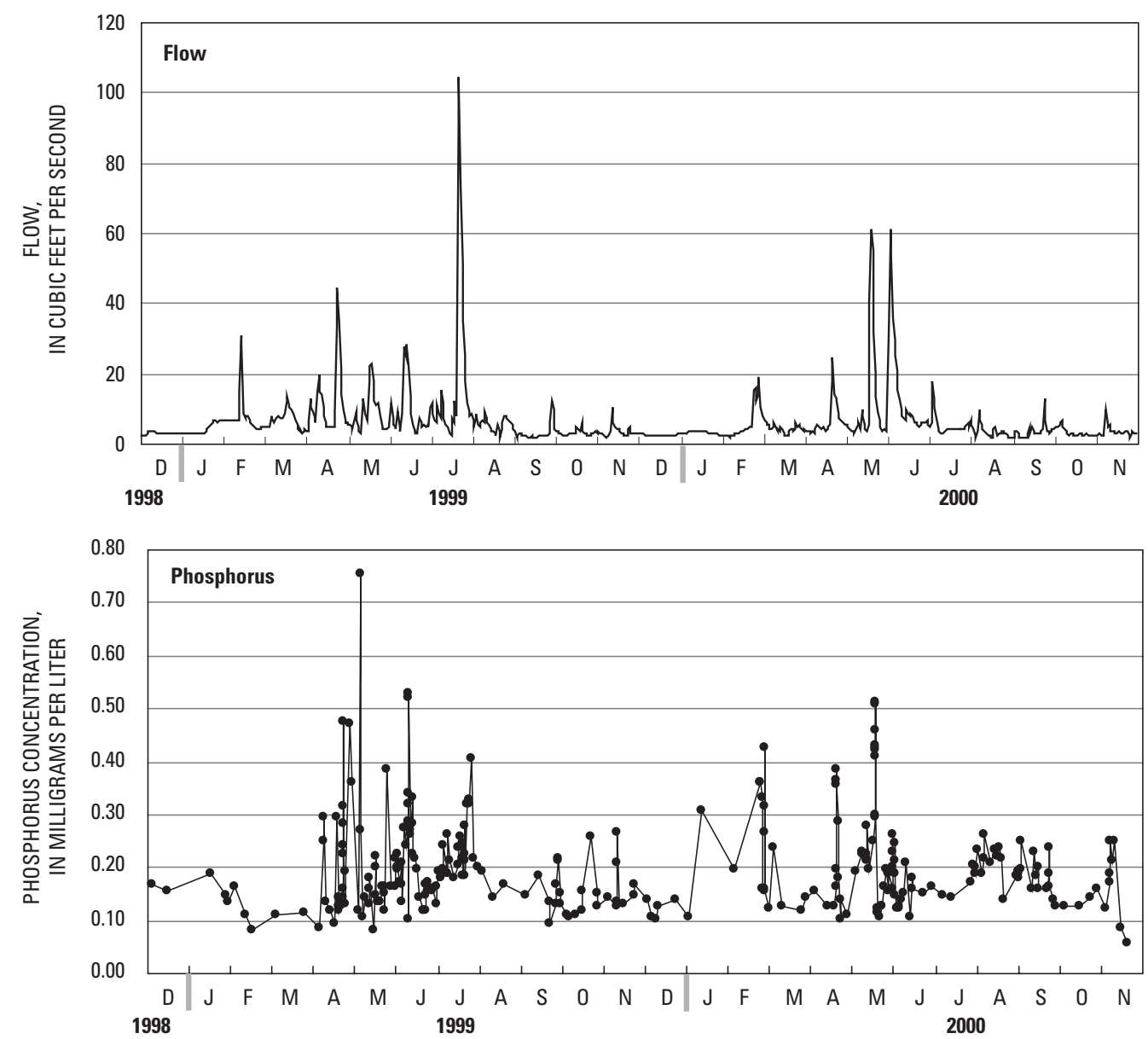

Figure 8. Daily average flow and instantaneous phosphorus concentrations in the Rubicon River at the inlet to Pike Lake near Hartford, Wis., December 1998 through November 2000. 
Greater than normal runoff was measured in 1999 in Cedar Creek near Cedarburg, Wisconsin, (12 percent greater than normal) about 18 miles east of Pike Lake, and the Fox River at Waukesha, Wisconsin, (11 percent greater than normal) about 20 miles south of Pike Lake. However, during 2000, flow in Cedar Creek was about 18 percent less than normal and flow in the Fox River was about 28 percent greater than normal. Hence, it is difficult to conclude whether runoff in MY2000 was greater or lesser than normal at Pike Lake based on these nearby streams.

\section{Surface-Water Outflow}

Surface-water outflow from the lake is to the Rubicon River at the outlet dam (fig. 2). Gate settings in the dam regulate flow from the lake. Daily average flow from the lake ranged from $0 \mathrm{ft}^{3} / \mathrm{s}$ to $80 \mathrm{ft}^{3} / \mathrm{s}$ (fig. 9). Annual outflow from the lake was 8,312 acre-ft, and 6,652 acre-ft, in MY1999 and MY2000, respectively (table 3).

\section{Evaporation}

Evaporation from the lake surface was estimated by applying a lake/pan coefficient to long-term average monthly pan evaporation for Madison, Wisconsin (Farnsworth and Thompson, 1982). Farnsworth and others (1982) estimated the annual lake/pan coefficient for the Pike Lake area to be 0.78 . It was assumed that during periods of ice cover on the lake, evaporation was zero and that the lake was ice covered from December through March. Annual evaporation was estimated to be 28.13 in. or 1,134 acre-ft (table 3).
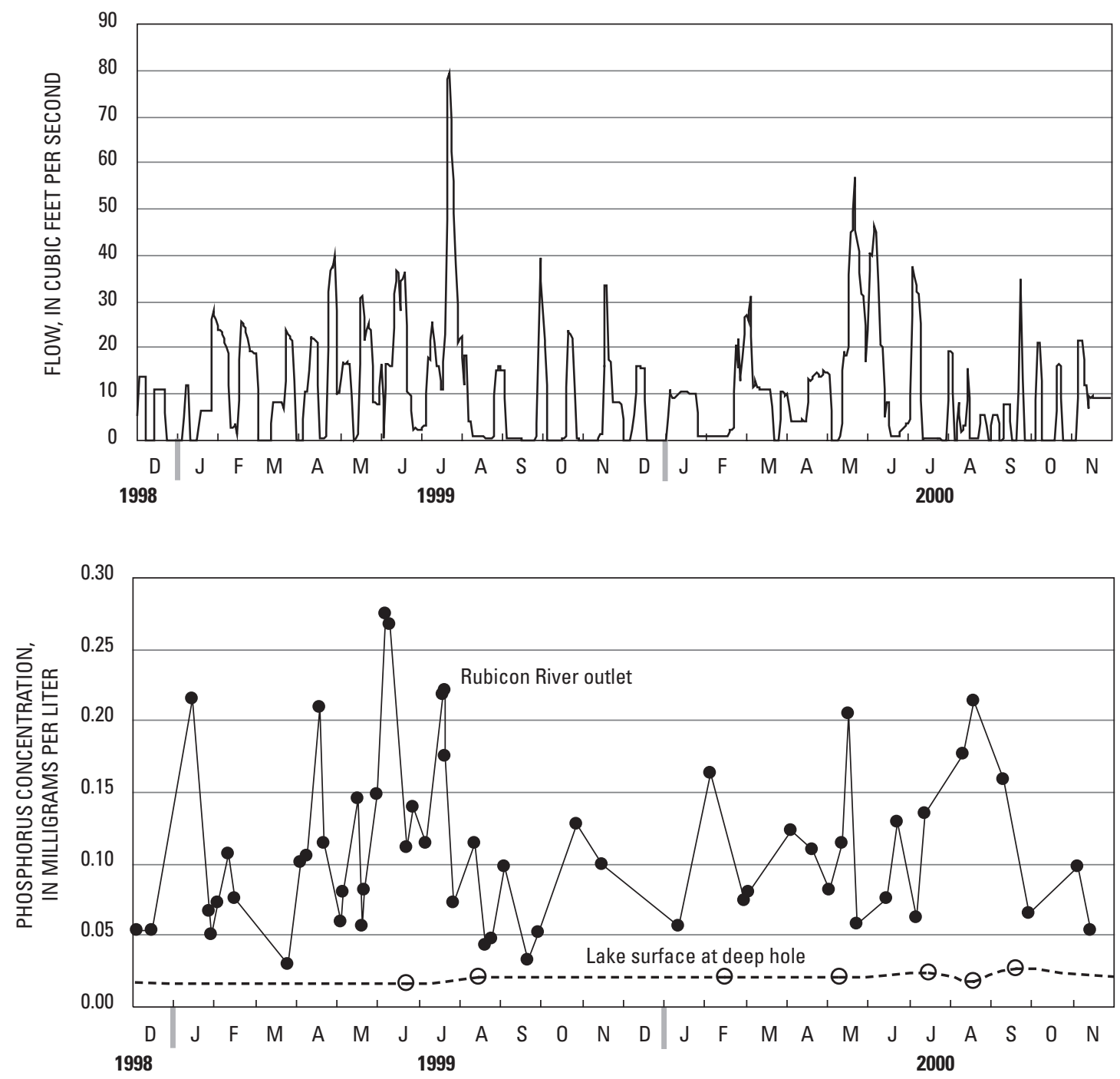

Figure 9. Daily average flow and instantaneous phosphorus concentrations in Rubicon River at the outlet of Pike Lake and surface phosphorus concentration at the deepest location in the lake, December 1998 through November 2000. 


\section{Ground-Water Inflow and Outflow}

Ground-water inflow was calculated as the residual in equation 7 after all other variables in the equation were measured or estimated. Two simplifying assumptions were (1) that ground-water outflow was negligibly small and (2) that the ground-water inflow rate was constant throughout the 2-year study. Assumption (1) is justified because data from piezometers installed around the periphery of the lake in the 1970s indicated that ground-water gradients were toward the lake except in a small region near the outlet (Wisconsin Department of Natural Resources, written commun., 1999). In addition, the appearance of groundwater seepage along the east and south shores of the lake indicates inflowing ground water. Although there probably was seasonal fluctuation in the magnitude of ground-water inflow, assumption (2) was necessary because data were not available to do a more detailed assessment of ground- water exchange with the lake. Ground water was estimated to have contributed about 620 acre-ft of water to the lake during each year of the study (table 3).

\section{Water Budget}

The Rubicon River is the largest source of water to Pike Lake, supplying about 55 percent of all water entering the lake during the 2-year study (table 3 and fig. 10). Of this, about 8 percent was from the Slinger WWTP. Other sources were precipitation (about 17 percent), ungaged near-lake surface inflow (about 21 percent), and ground water (about 7 percent). Inputs in MY1999 (9,560 acre$\mathrm{ft})$ were greater than inputs in MY2000 (7,701 acre-ft), because there were more numerous and greater-magnitude storms in MY1999.

Water outputs from the lake were similar to water inputs because there was little difference in lake storage

Water inputs, monitoring ear 2000

(Total input 7,701 acre-feet)

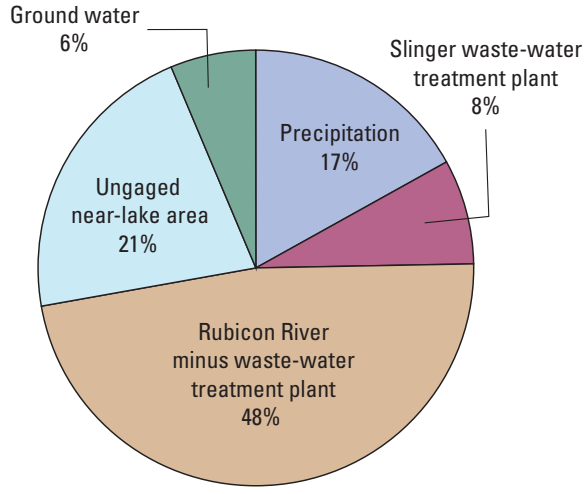

Ground water

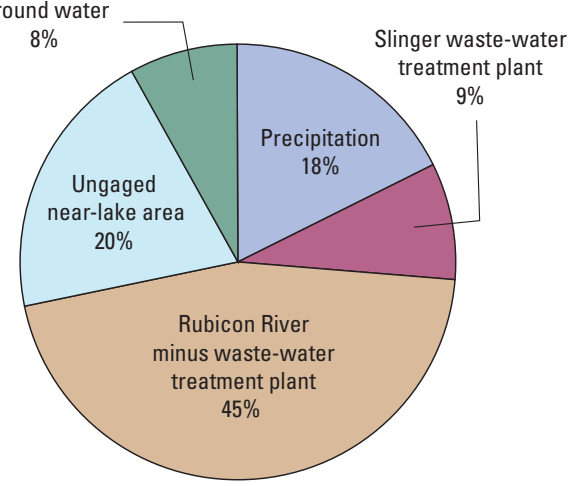

Water outputs, monitoring ear 1999

(Total input $\quad 9,446$ acre-feet)

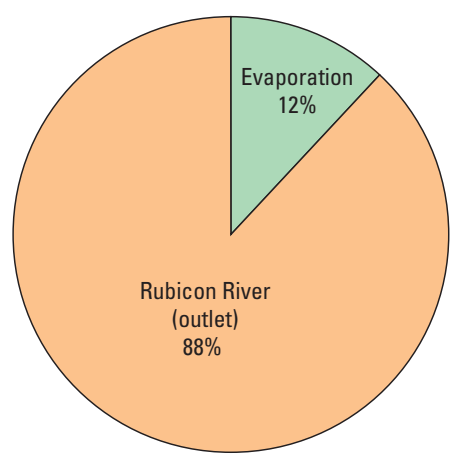

Water outputs, monitoring ear 2000

(Total input 7,786 acre-feet)

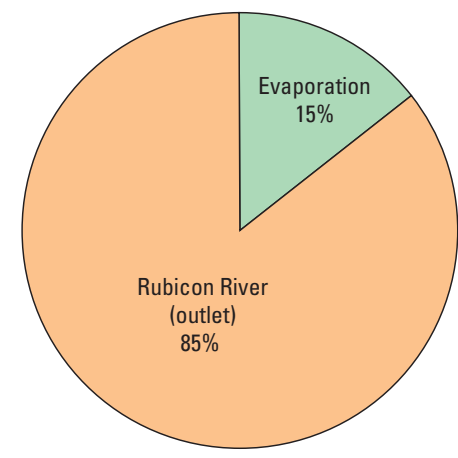

Figure 10. Water budget for Pike Lake, near Hartford, Wis., for monitoring years 1999 and 2000. [Monitoring year, December to November; \%, percent] 
from beginning to end of either study year. The largest output (about 87 percent, fig. 10) of water from the lake was through the outlet into Rubicon River. Evaporation accounted for about 13 percent of the outputs.

The quality of the water budget can be evaluated by comparing the calculated water levels for the lake with those measured during the 2-year period (fig. 6). The differences between calculated and measured water levels reflect the cumulative errors in the estimates of daily water-budget components. The calculated water level fluctuated within about $0.5 \mathrm{ft}$ of the measured lake level. The assumptions that were necessary in estimating evaporation and ground-water inflow are likely to have contributed much of the difference between calculated and measured water levels. The long-term average estimates of evaporation that were used for this study could be different than actual evaporation during the two study years. Groundwater inflow was applied uniformly throughout the 2 years when, in fact, seasonal fluctuation was likely.

\section{Phosphorus Sources to Pike Lake}

To determine the main sources of phosphorus and to identify where water-resource managers could focus efforts to reduce phosphorus contributions to the lake, a detailed phosphorus budget was calculated. The equation for the phosphorus budget (Eq. 8) is similar to the equation for the water budget (Eq. 7) except there is no term for evaporation, because evaporation does not remove phosphorus. The subscript "p" indicates a quantity of phosphorus is represented.

$$
\mathrm{R}_{\mathrm{p}}=\left(\mathrm{PPT}+\mathrm{SW}_{\text {In }}+\mathrm{GW}_{\text {In }}\right)_{\mathrm{p}}-\left(\mathrm{SW}_{\text {out }}+\mathrm{GW}_{\text {out }}\right)_{\mathrm{p}}
$$

Data were not available to do an independent determination of the change in phosphorus stored in lake water and sediment. Hence, the residual (Rp) in equation 8 is composed of the change of phosphorus stored in lake water and sediment and the net error of all independently determined budget components.

\section{Precipitation}

Phosphorus input to the lake from precipitation was estimated by multiplying daily precipitation volumes by an estimated phosphorus concentration of $0.016 \mathrm{mg} / \mathrm{L}$. Field and Duerk (1988) determined that bulk precipitation at Delavan Lake, which is about $40 \mathrm{mi}$. south of Pike Lake, had an average concentration of $0.016 \mathrm{mg} / \mathrm{L}$ during 1984 and 1985. Phosphorus inputs to the lake from precipitation were 70 lbs in MY1999 and 60 lbs in MY2000 (table 4).

Table 4. Phosphorus budget for Pike Lake near Hartford, Wis., monitoring years 1999 and 2000

[Monitoring year, December-November; MY, monitoring year; all data in pounds or percentage of total; WWTP, waste-water treatment plant]

\begin{tabular}{|c|c|c|c|c|c|c|}
\hline Budget component & MY1999 & $\begin{array}{c}\text { MY1999 } \\
\text { (percent) }\end{array}$ & MY2000 & $\begin{array}{c}\text { MY2000 } \\
\text { (percent) }\end{array}$ & $\begin{array}{l}\text { Two-year } \\
\text { average }\end{array}$ & $\begin{array}{c}\text { Two-year } \\
\text { average (percent) }\end{array}$ \\
\hline \multicolumn{7}{|c|}{ Inputs to lake } \\
\hline Precipitation & 70 & 2.0 & 60 & 2.4 & 65 & 2.2 \\
\hline Rubicon River (inlet) & 2,714 & 78.2 & 1,936 & 79.3 & 2,325 & 78.7 \\
\hline Slinger WWTP & 1,283 & 37.0 & 1,039 & 42.6 & 1,161 & 39.3 \\
\hline Rubicon River minus WWTP & 1,431 & 41.3 & 897 & 36.7 & 1,164 & 39.4 \\
\hline Ungaged near-lake area & 640 & 18.5 & 401 & 16.4 & 521 & 17.6 \\
\hline Ground water $^{1}$ & 44 & 1.3 & 44 & 1.8 & 44 & 1.5 \\
\hline Total input & 3,469 & 100.0 & 2,441 & 100.0 & 2,955 & 100.0 \\
\hline \multicolumn{7}{|c|}{ Outputs from lake } \\
\hline Evaporation & 0 & 0 & 0 & 0 & 0 & 0 \\
\hline Rubicon River (outlet) & 2,504 & 100 & 1,678 & 100 & 2,091 & 100 \\
\hline Ground water ${ }^{1}$ & 0 & 0 & 0 & 0 & 0 & 0 \\
\hline Total output & 2,504 & 100 & 1,678 & 100 & 2,091 & 100 \\
\hline
\end{tabular}

${ }^{1}$ It was assumed that there was no ground-water recharge from the lake. 

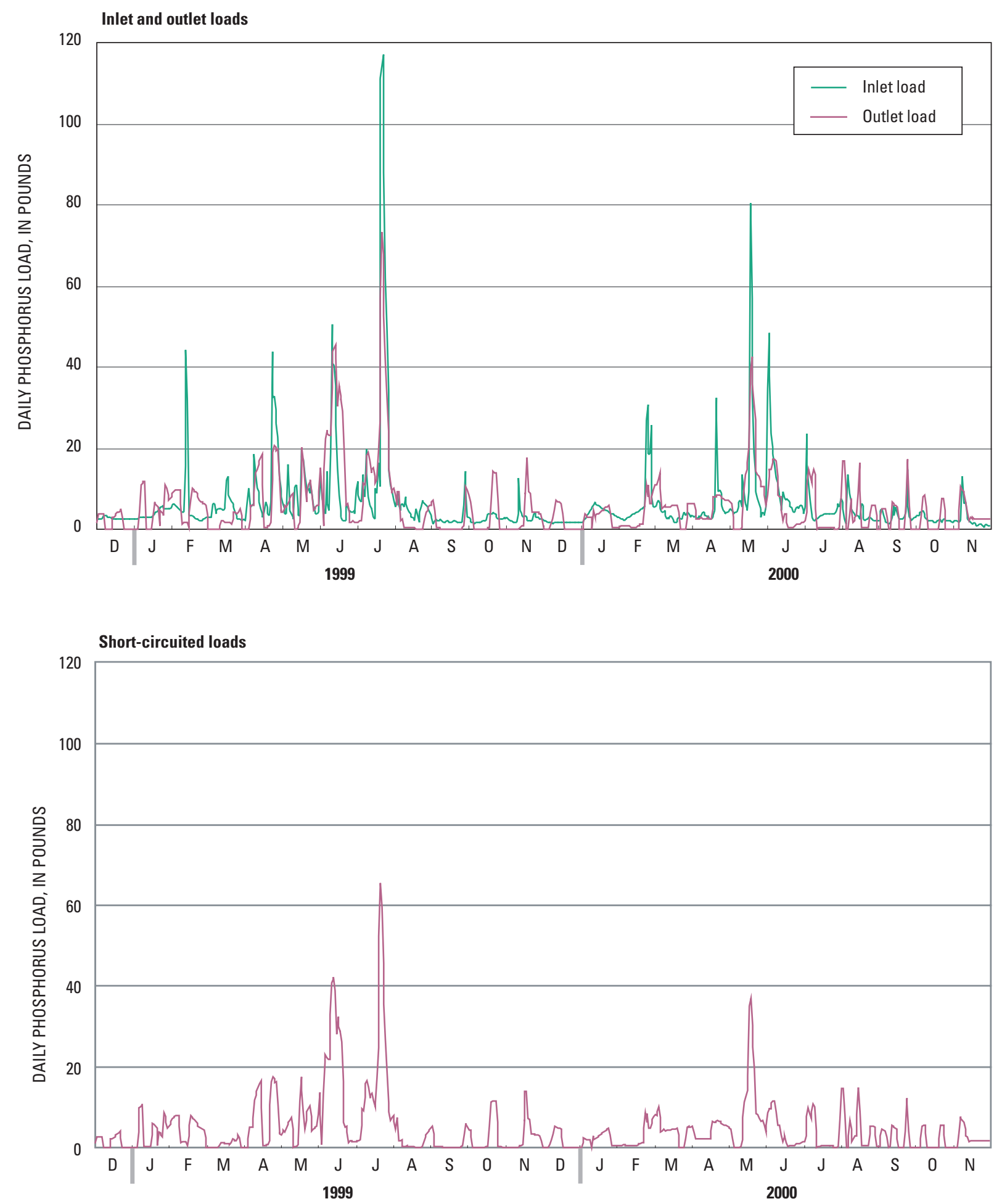

Figure 11. Daily phosphorus loads at the Rubicon River inlet to and outlet from Pike Lake, Wis., and the estimated part of inlet load short-circuited from the inlet to the outlet, December 1998-November 2000. 


\section{Surface-Water Inflow and Outflow}

Phosphorus loads for the monitoring sites at the Rubicon River inlet to the lake and the Rubicon River outlet from the lake were calculated by use of techniques for integrating streamflow and concentration described by Porterfield (1972) (fig. 11). The loading determined for the inlet site included contributions from the watershed and contributions from the Slinger WWTP, which discharges into the Rubicon River about 2 mi upstream of the monitoring site. Because of the proximity of the inlet and outlet to each other, an estimate of inlet-to-outlet short-circuiting was determined. Phosphorus loading information for the Rubicon River inlet was used to estimate loading from the ungaged near-shore areas.

\section{Rubicon River Inlet}

Phosphorus passing the Rubicon River inlet monitoring site is derived from the watershed and from the Slinger WWTP. Phosphorus concentrations for 281 samples collected in the Rubicon River during the 2-year study ranged from 0.058 to $0.756 \mathrm{mg} / \mathrm{L}$ (fig. 8). The flow-weighted average concentration was $0.181 \mathrm{mg} / \mathrm{L}$. On average, about 61 percent of total phosphorus was in a dissolved form. The total amount of phosphorus delivered to the lake/marsh system by the Rubicon River was $2,714 \mathrm{lbs}$ in MY1999 and 1,936 lbs in MY2000 (table 4). Of these totals, the Slinger WWTP discharged 1,283 lbs and 1,039 lbs, in MY1999 and MY2000 respectively (G. D. Moser, Slinger Wastewater Treatment Plant, written commun., 2002). Therefore, the unit-area yields from the Rubicon River (after Slinger WWTP inputs were removed) were $180 \mathrm{lb} / \mathrm{mi}^{2}$ in MY1999 and $113 \mathrm{lb} / \mathrm{mi}^{2}$ in MY2000.

\section{Rubicon River Outlet}

Phosphorus is discharged from Pike Lake into the Rubicon River at the outlet from the lake when there is flow through the gates in the dam. Phosphorus concentrations in 66 samples collected during the 2-year study ranged from 0.030 to $0.314 \mathrm{mg} / \mathrm{L}$ (fig. 9). The flowweighted average concentration was $0.103 \mathrm{mg} / \mathrm{L}$. The Rubicon River received 2,504 lbs of phosphorus from the lake in MY1999 and 1,678 lbs in MY2000 (table 4).

\section{Inlet-to-Outlet Short-Circuiting}

Phosphorus concentrations in water leaving the outlet of Pike Lake generally were 2 to 10 times greater than concentrations at the surface at the deep-hole sampling site in the lake (fig. 9). The average concentration of phosphorus at the surface of the lake was about $0.020 \mathrm{mg} / \mathrm{L}$ compared with a flow-weighted average outflow concentration of $0.103 \mathrm{mg} / \mathrm{L}$. This suggests that there is considerable "short-circuiting" of water from the lake's inlet to the outlet. If there was no short-circuiting, the concentration of phosphorus in water leaving the lake would be expected to be similar to the concentration of phosphorus in the lake's near-surface water.

Because of the short-circuiting, much of the phosphorus that enters the lake from the Rubicon River does not enter and mix with water in the main body of the lake. In MY1999, approximately 2,500 lbs of phosphorus were exported out of the lake; only about $400 \mathrm{lbs}$ would have been exported if water from the center of the lake were removed. Therefore, there was an effective short-circuiting of over 77 percent of the phosphorus. In MY2000, approximately 1,680 lbs of phosphorus were exported out of the lake; only about $407 \mathrm{lbs}$ would have been exported if water from the center of the lake were removed. Therefore, there was an effective short-circuiting of over 65 percent of the phosphorus. This effective short-circuiting of phosphorus was only partially achieved by direct hydraulic short-circuiting of water from the inlet to the outlet. The marsh and river channel through the marsh mediated the inlet-to-outlet transfer of phosphorus. From figure 11, it is evident that part of the time the delivery of phosphorus to the lake-marsh system from the inlet was greater than the removal of phosphorus from the lake-marsh system by the outlet and vice versa.

\section{Ungaged Near-Lake Areas}

Phosphorus loading from ungaged near-lake runoff was estimated based on the assumption that unit-area yields of phosphorus from ungaged near-lake areas were the same as unit-area yields for the Rubicon River watershed upstream of Pike Lake after removing contributions from the Slinger WWTP. Phosphorus loads from the near-lake ungaged areas were estimated to be 640 pounds (180 lbs/mi² x $3.56 \mathrm{mi}^{2}$ ) in MY1999 and 401 pounds (113 lbs/mi x $3.56 \mathrm{mi}^{2}$ ) in MY2000 (table 4).

\section{Ground Water}

Phosphorus delivered to the lake by ground-water inflow was estimated to be $44 \mathrm{lbs}$ in MY1999 and MY2000 (table 4). This estimate is based on a concentra- 
tion of $0.026 \mathrm{mg} / \mathrm{L}$ for ground water entering the lake. The average phosphorus concentration of water from six water-table wells in eastern Washington County was 0.026 $\mathrm{mg} / \mathrm{L}$ (Saad, 1997).

\section{Phosphorus Budget}

Approximately 3,470 lbs of phosphorus was delivered to the lake in MY1999 compared to approximately 2,440 lbs in MY2000 (table 4). The largest source of phosphorus entering Pike Lake is the Rubicon River, which delivered about 80 percent of all phosphorus entering the lake/marsh system (fig. 12A and 12B); the Slinger WWTP supplied

\section{Without inlet-to-outlet short-circuiting}

A

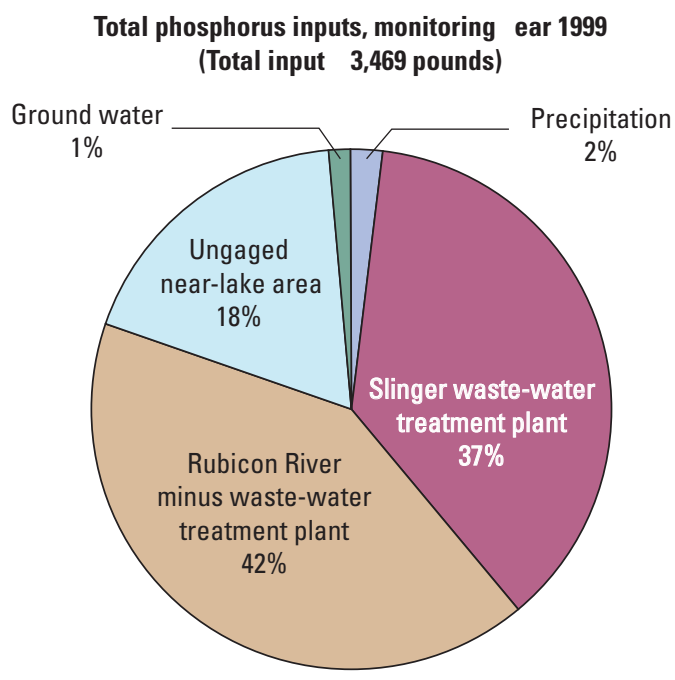

B

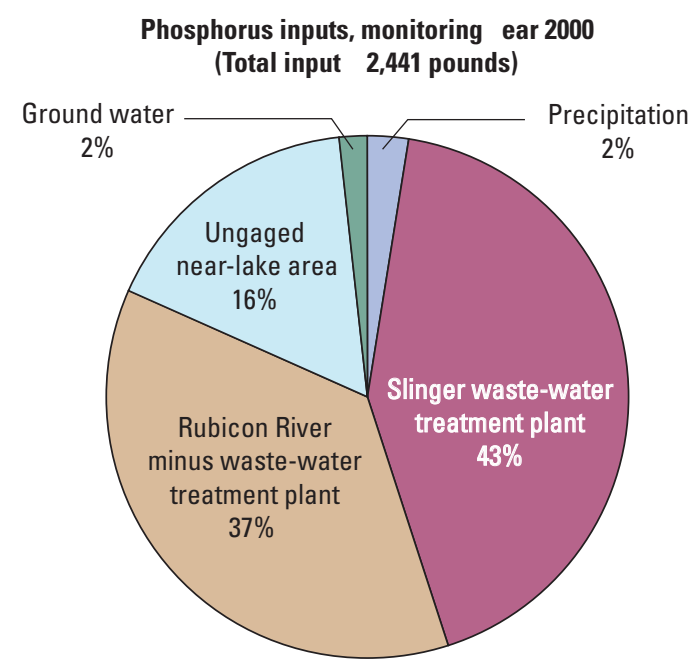

about half of this phosphorus. Ungaged near-lake inflow, ground water, and precipitation accounted for about 18.6, 1.5, and 2.2 percent, respectively, of the phosphorus loading to the lake. Phosphorus loading in MY1999 was about 1.4 times greater than in MY2000 due to greater storms and accompanying precipitation in MY1999 than in MY2000.

Because of the short-circuiting, much of the phosphorus measured at the inlet site on the Rubicon River does not enter the main body of the lake, whereas most of the phosphorus from the other sources does enter the main body of the lake. As a result, the gross inputs of phosphorus from the Rubicon River were reduced by approxi-

\section{With inlet-to-outlet short-circuiting}

C

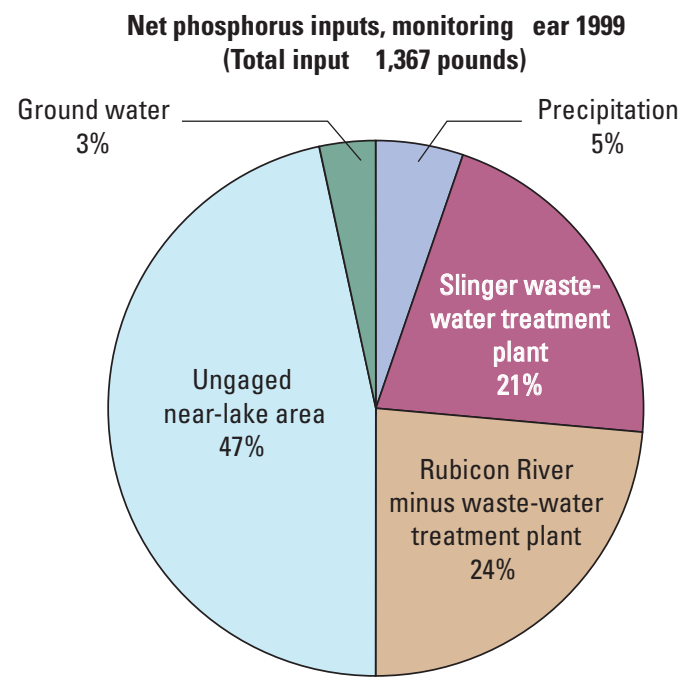

D

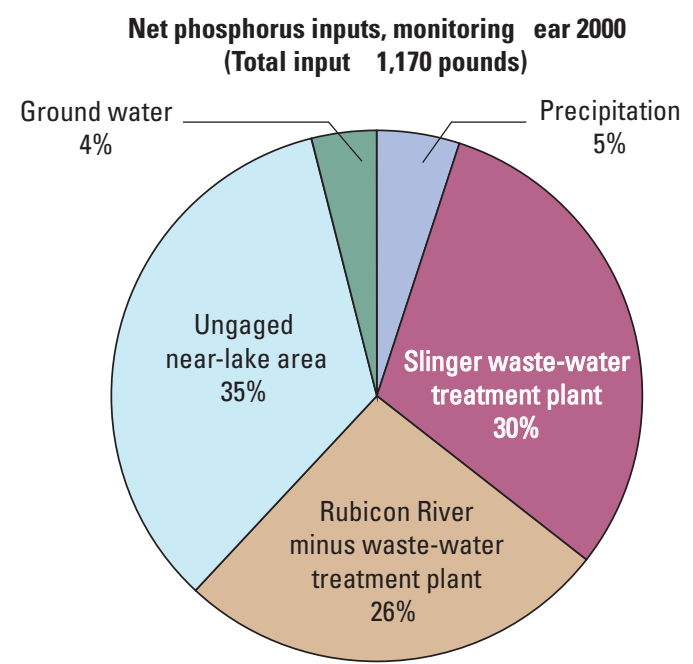

Figure 12. Phosphorus budgets for Pike Lake, near Hartford, Wis., for monitoring years 1999 and 2000. [Monitoring year, December to November; \%, percent] 
mately 77 percent in MY1999 and 65 percent in MY2000 (fig. 12C and 12D); the net phosphorus input was 1,367 lbs in MY1999 and 1,170 lbs in MY2000. In MY1999, the ungaged near-lake areas were the dominant source of phosphorus (47 percent) and the Rubicon River was the secondary source (45 percent, almost equally subdivided between the WWTP and watershed contributions). In MY2000, the inputs from the ungaged near-lake areas (35 percent), WWTP (30 percent), and Rubicon River watershed contributions (26 percent) were of similar magnitude. Because of the short-circuiting, direct inputs from the watershed area south of Highway 60 were much more significant than if short-circuiting had not occurred.

\section{Allocation of Tributary Loading}

To delineate further where the phosphorus from the Rubicon River and ungaged near-lake areas originates, the effective load for MY2000 (the more typical hydrologic and loading year of the two years sampled) was allocated to various land uses/land covers on the basis of the export rates (unit-area loading) in table 5 and the percentage of the watershed with the various land uses/land covers. Specific unit-area export rates for the land uses/land covers upstream of the inlet gage were reduced by 65 percent because of the short-circuiting that was estimated for MY2000. Loads computed on the basis of these export rates provided an effective load for the gaged and ungaged areas similar to that estimated for MY2000. The unit-area yields required to match the measured loads were relatively low compared to those used in similar lake-modeling studies in southern Wisconsin (Panuska and Krieder, 2002; Robertson and others, 2002) and those measured in streams in southern Wisconsin (Corsi and others, 2002). The total contribution from each land-use/land-cover category and source is shown in figure 13. Of the overall phosphorus load, agricultural land contributed over 44 percent of the load (26 percent from agricultural areas in the ungaged near-lake areas and 18 percent from the upstream area). The Slinger WWTP contributed about 30 percent of the entire load. Urban areas, although having relatively high unit-area loading, only contributed a small percentage of the entire load because they represent only a small percentage of the entire watershed.

\section{Response in Water Quality to Changes in Phosphorus Loading}

Empirical models that relate phosphorus loading to measured water quality can be used to determine how changes in phosphorus loading would affect the water quality of Pike Lake, and how much of the phosphorus input into the lake would need to be eliminated to improve its water. These models were developed by comparing hydrologic and phosphorus loadings for many different lakes and reservoirs with parameters describing lake-water quality, such as near-surface phosphorus and chlorophyll $a$ concentrations and Secchi depth. Several of these empirical models are part of the Wisconsin Lakes Modeling Suite (WiLMS) (Panuska and Kreider, 2002).

To predict the expected changes in water quality in Pike Lake in response to changes in phosphorus loading, 13 scenarios (table 6) were simulated with WiLMS. Scenario 1 involves a simulation of the base case with which to compare other simulations. Six basin-wide strategies are presented in scenarios $2-7$, which have decreases in all controllable phosphorus loading (not including that from precipitation and ground water) by 50 and 25 percent, and increases in controllable phosphorus loading by 25,50 , 75 , and 100 percent, respectively. Scenarios 8-13 include changes in short-circuiting or loading from point sources.

Scenarios 8-11 (table 6) were simulated to determine how changes in short-circuiting associated with possible morphometric changes near the point of entry of the Rubicon River to the lake could alter the water quality of the lake. Scenario 8 (no short-circuiting) simulated conditions where all of the water from the Rubicon River would directly discharge into the main body of the lake. Scenarios 9 and 10 (short-circuiting of 75 and 100 percent of the phosphorus, respectively), simulated conditions where more phosphorus was either short-circuited or eliminated from the inflow. Scenario 11, short-circuiting of 100 percent of the water and phosphorus, simulated conditions where the Rubicon River (water and nutrients) was completely diverted from the lake.

Two scenarios examined changes in the amount of point sources discharged into the Rubicon River: scenario 12 simulated complete elimination of all phosphorus discharged from the Slinger WWTP to the Rubicon River, and scenario 13 simulated a 100 percent increase (doubling) of phosphorus from the WWTP.

Hydrologic loading, and water-quality data from MY2000 were used to test the models and compare the predicted responses. This period was chosen because it 
Table 5. Allocation of phosphorus loading to land-use/land-cover categories in the Pike Lake watershed [ $\mathrm{mi}^{2}$, square miles; $1 \mathrm{bs} / \mathrm{mi}^{2}$, pounds per square mile; WWTP, waste-water treatment plant; NA, not applicable]

\begin{tabular}{|c|c|c|c|c|c|}
\hline Land use/land cover and other sources & $\begin{array}{l}\text { Area } \\
\left(\mathrm{mi}^{2}\right)\end{array}$ & $\begin{array}{l}\text { Percentage } \\
\text { of total area }\end{array}$ & $\begin{array}{c}\text { Unit-area } \\
\text { export rate } \\
\text { (lbs/mi²) }\end{array}$ & $\begin{array}{c}\text { Total } \\
\text { phosphorus } \\
\text { load (Ibs) }\end{array}$ & $\begin{array}{l}\text { Percentage of } \\
\text { total load }\end{array}$ \\
\hline \multicolumn{6}{|c|}{ Gaged area (north of Highway 60) } \\
\hline Urban high and moderate density & 0.44 & 3.6 & 68.5 & 29.9 & 2.6 \\
\hline Rural residential & .53 & 4.3 & 18.8 & 10.0 & 0.9 \\
\hline Agriculture & 3.48 & 28.3 & 59.9 & 208.2 & 17.8 \\
\hline Pasture/grassland & 1.13 & 9.2 & 25.1 & 28.4 & 2.4 \\
\hline Forest & 1.18 & 9.6 & 9.7 & 11.4 & 1.0 \\
\hline Open water & .01 & 0.1 & 27.4 & 0.3 & .0 \\
\hline Wetland & 1.20 & 9.8 & 17.1 & 20.5 & 1.7 \\
\hline Slinger WWTP & NA & NA & NA & 357.2 & 30.5 \\
\hline \multicolumn{6}{|c|}{ Ungaged near-lake area (south of Highway 60) } \\
\hline Urban high and moderate density & .03 & .2 & 199.8 & 5.3 & .5 \\
\hline Rural residential & .18 & 1.5 & 57.1 & 10.3 & .9 \\
\hline Agriculture & 1.84 & 15.0 & 167.9 & 309.2 & 26.4 \\
\hline Pasture/grassland & .47 & 3.8 & 74.2 & 34.7 & 3.0 \\
\hline Forest & .66 & 5.3 & 28.5 & 18.7 & 1.6 \\
\hline Open water & .03 & .2 & 79.9 & 2.3 & .2 \\
\hline Wetland & .39 & 3.2 & 51.4 & 20.0 & 1.7 \\
\hline \multicolumn{6}{|c|}{ Other sources } \\
\hline Precipitation (lake surface) & 0.72 & 5.8 & 83.7 & 60.0 & 5.1 \\
\hline Ground water & NA & NA & NA & 44.0 & 3.8 \\
\hline Total & 12.26 & 100.0 & NA & $1,170.4$ & 100.0 \\
\hline
\end{tabular}

had the most extensive water-quality data for the lake and because the hydrologic conditions were closest to average.

\section{Response in Water Quality to Basin-Wide Changes in Phosphorus Loading}

Of the 13 empirical models contained in WiLMS, 9 were applicable to the hydrologic system of Pike Lake. Therefore, the morphometry of the lake and the hydrologic and phosphorus loadings for MY2000 were input into these models to simulate near-surface phosphorus concentrations for the lake. The various phosphorus-loading scenarios, with the associated effective phosphorus loading from the Rubicon River (table 6), then were input into these models to predict changes in near-surface phosphorus concentrations. All of the models within WiLMS use annual hydrologic and phosphorus loadings, but simulate the water quality for different discrete seasons. There are no calibration factors in WiLMS; however, the output can be adjusted to account for model biases by interpreting the results as a percentage change from a base condition.

The average simulated phosphorus concentration for Pike Lake was $0.028 \mathrm{mg} / \mathrm{L}$ when all phosphorus inputs for MY2000 were included in the models (table 7). This value is slightly more $(0.006 \mu \mathrm{g} / \mathrm{L})$ than the average of the seasonally summarized data measured in the lake $(0.022$ $\mathrm{mg} / \mathrm{L}$ ). The models then were applied with the controllable phosphorus load (entire external load not including inputs from precipitation and ground water) decreased and increased by the specified percentages. All of the changes in phosphorus loading (in $\mathrm{mg} / \mathrm{L}$ and percent) are listed in table 6. With a 50-percent reduction in phosphorus loading, the average simulated phosphorus concentration was $0.017 \mathrm{mg} / \mathrm{L}$ (a decrease of $0.011 \mathrm{mg} / \mathrm{L}$ or about 40 percent; table 7). With a 50-percent increase in phosphorus loading, the average simulated concentration was $0.039 \mathrm{mg} / \mathrm{L}$ 
Allocation of phosphorus load

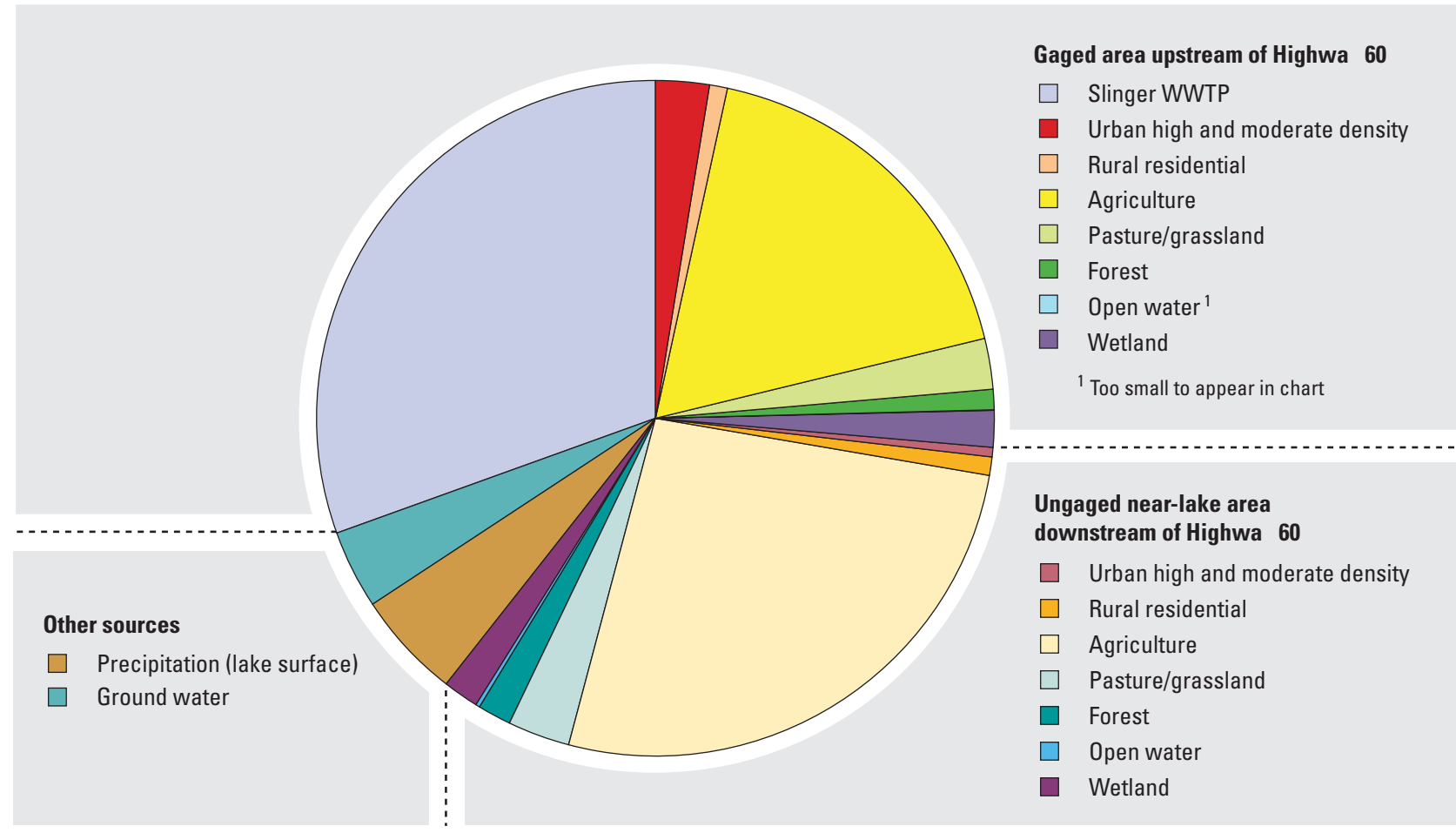

Figure 13. Allocation of phosphorus load on the basis of land use/land cover to Pike Lake, near Hartford, Wis., for 2000.

Table 6. Contributions of phosphorus, by source, for various phosphorus-loading scenarios for Pike Lake near Hartford, Wis. Base scenario has 65-percent short-circuiting of phosphorus. Scenarios 2-7 simulate changes in controllable phosphorus loading with 65-percent short-circuiting

$[\%$, percent]

\begin{tabular}{|c|c|c|c|c|c|c|c|}
\hline \multicolumn{2}{|r|}{ Scenario } & \multicolumn{6}{|c|}{ Phosphorus source (pounds) } \\
\hline Number & Description & $\begin{array}{l}\text { Precip- } \\
\text { itation }\end{array}$ & $\begin{array}{c}\text { Ground } \\
\text { water }\end{array}$ & $\begin{array}{c}\text { Point } \\
\text { sources }\end{array}$ & $\begin{array}{c}\text { Nonpoint } \\
\text { sources } \\
\text { north of } \\
\text { Highway } 60\end{array}$ & $\begin{array}{c}\text { Nonpoint } \\
\text { sources } \\
\text { south of } \\
\text { Highway } 60\end{array}$ & $\begin{array}{l}\text { Total } \\
\text { input }\end{array}$ \\
\hline 1 & Base (2000); 65\% short-circuiting of phosphorus & 60 & 44 & 357 & 309 & 401 & 1,171 \\
\hline 2 & $50 \%$ decrease in controllable phosphorus sources & 60 & 44 & 179 & 154 & 201 & 637 \\
\hline 3 & $25 \%$ decrease in controllable phosphorus sources & 60 & 44 & 268 & 232 & 301 & 904 \\
\hline 4 & $25 \%$ increase in controllable phosphorus sources & 60 & 44 & 447 & 386 & 502 & 1,438 \\
\hline 5 & $50 \%$ increase in controllable phosphorus sources & 60 & 44 & 536 & 463 & 602 & 1,704 \\
\hline 6 & $75 \%$ increase in controllable phosphorus sources & 60 & 44 & 625 & 540 & 702 & 1,971 \\
\hline 7 & $100 \%$ increase in controllable phosphorus sources & 60 & 44 & 714 & 617 & 803 & 2,238 \\
\hline 8 & No short-circuiting & 60 & 44 & 1,039 & 897 & 401 & 2,441 \\
\hline 9 & $75 \%$ short-circuiting of phosphorus & 60 & 44 & 260 & 225 & 401 & 990 \\
\hline 10 & $100 \%$ short-circuiting (elimination) of phosphorus & 60 & 44 & 0 & 0 & 401 & 505 \\
\hline 11 & $100 \%$ short-circuiting of water and phosphorus & 60 & 44 & 0 & 0 & 401 & 505 \\
\hline 12 & Elimination of all point sources of phosphorus & 60 & 44 & 0 & 309 & 401 & 814 \\
\hline 13 & $100 \%$ increase in point sources of phosphorus & 60 & 44 & 714 & 309 & 401 & $\mathbf{1 , 5 2 8}$ \\
\hline
\end{tabular}


22 Water Quality, Hydrology, and the Effects of Changes in Phosphorus Loading to Pike Lake, Washington County, Wis.
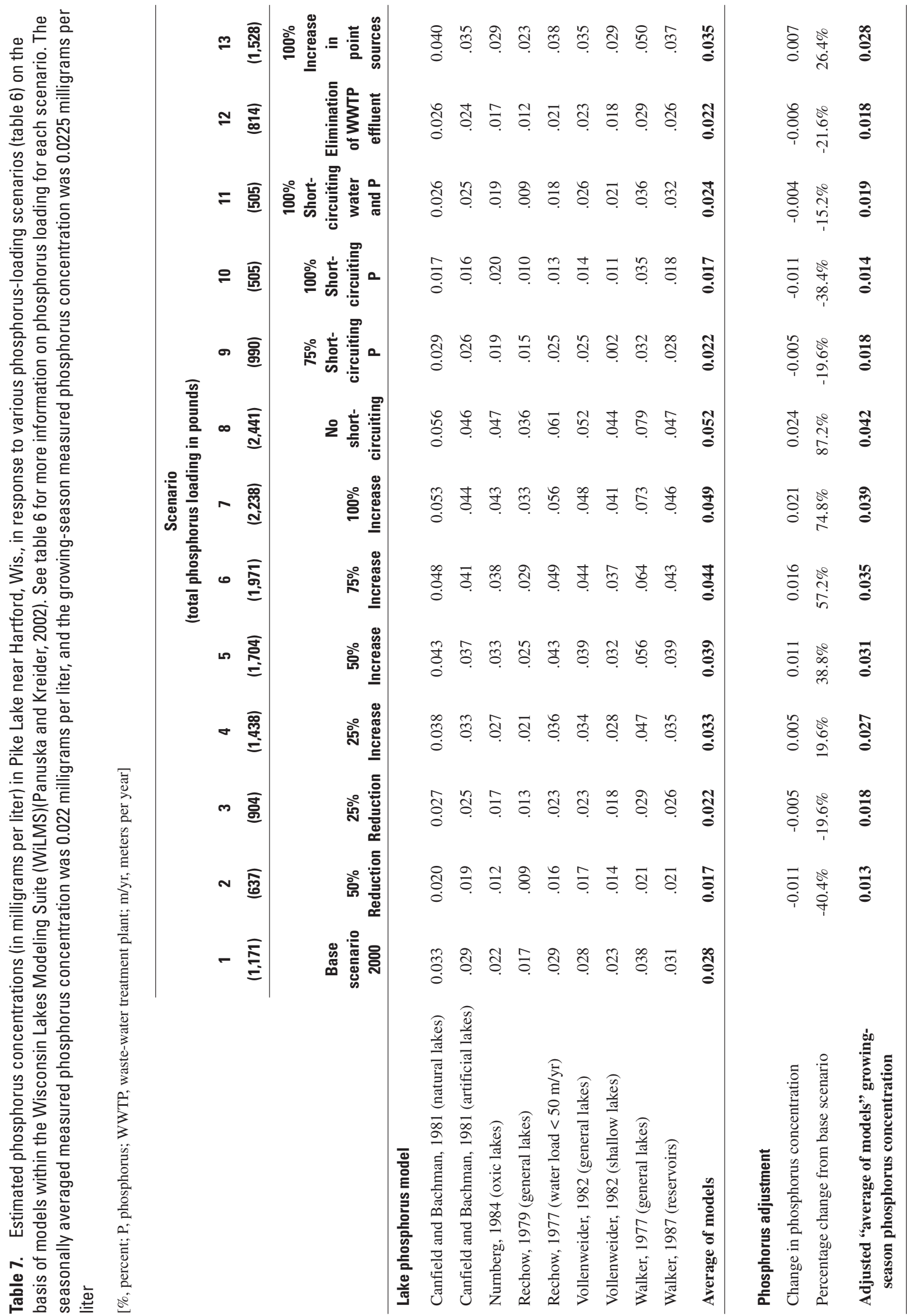
(an increase of about $0.011 \mathrm{mg} / \mathrm{L}$ or about 39 percent), and with a 100-percent increase in loading, the average simulated phosphorus concentration was $0.049 \mathrm{mg} / \mathrm{L}$ (an increase of about $0.021 \mathrm{mg} / \mathrm{L}$ or about 75 percent). If it is assumed that these percentage changes also apply to the summer-average concentration measured in Pike Lake of $0.0225 \mathrm{mg} / \mathrm{L}$, then according to the simulations, a 50-percent reduction in loading would result in a summer-average concentration of $0.013 \mathrm{mg} / \mathrm{L}$, a 50 -percent increase in loading would result in $0.031 \mathrm{mg} / \mathrm{L}$, and a 100 -percent increase would result in $0.039 \mathrm{mg} / \mathrm{L}$ (table 7). Phosphorus concentrations had a relatively linear response to a linear change in phosphorus loading (fig. 14); however, on a percentage basis, the changes in phosphorus concentrations were not as large as the changes in phosphorus loadings. Changes in phosphorus concentrations were about 75 percent of the changes in phosphorus loading. In other words, a 50-percent increase in phosphorus loading causes a 38-40-percent increase in the lake's phosphorus concentrations.

Empirical relations also have been developed that predict summer-average chlorophyll $a$ concentrations and Secchi depths from near-surface phosphorus concentrations. Empirical relations developed for Wisconsin lakes by Lillie and others (1993), also contained within WiLMS, were applied to determine how the various reductions in controllable phosphorus loading would affect near-surface chlorophyll $a$ concentrations and Secchi depths in Pike Lake. These models predicted that with the measured summer-average phosphorus concentration of $0.0225 \mathrm{mg} / \mathrm{L}$, the lake should have a chlorophyll $a$ concentration of 7.3 $\mu \mathrm{g} / \mathrm{L}$ (compared to $7.1 \mu \mathrm{g} / \mathrm{L}$ measured in the summer of 2000, table 8) and a Secchi depth of $6.2 \mathrm{ft}$ (similar to that measured in 2000). The predicted summer-average phosphorus concentrations (table 7) were then input into the empirical relations and the results are shown in table 8. With a near-surface phosphorus concentration of 0.013 $\mu \mathrm{g} / \mathrm{L}$ (50-percent reduction scenario), the models predicted a chlorophyll $a$ concentration of $5.2 \mu \mathrm{g} / \mathrm{L}$ (a 29-percent reduction from $7.3 \mu \mathrm{g} / \mathrm{L}$ predicted for $0.0225 \mathrm{mg} / \mathrm{L}$ of phosphorus) and a Secchi depth of $7.9 \mathrm{ft}$ (an increase of 26 percent from $6.2 \mathrm{ft}$ predicted for $0.0225 \mathrm{mg} / \mathrm{L}$ of phosphorus). With a near-surface phosphorus concentration of $0.039 \mathrm{mg} / \mathrm{L}$ (100-percent increase scenario), the models predicted a chlorophyll $a$ concentration of $10.4 \mu \mathrm{g} / \mathrm{L}$ (a 43 -percent increase from that predicted for $0.0225 \mathrm{mg} / \mathrm{L}$ of phosphorus) and a Secchi depth of $4.9 \mathrm{ft}$ (a decrease of 21 percent).

If it is again assumed that the models should be used only to predict the percentage of change (although they were very accurate and few changes were needed), then these results can be used to predict changes from the summer-average concentrations measured in 2000 (figs. 15 and 16). Chlorophyll $a$ concentrations have a relatively linear response to a reduction in phosphorus loading. However, for increases in phosphorus loading, the percentage response for chlorophyll $a$ was smaller than for load reductions (fig. 15). For example, a 50-percent reduction in phosphorus loading resulted in about a 29-percent reduction in chlorophyll $a$, whereas a 50-percent increase in phosphorus loading resulted in a 24-percent increase in chlorophyll $a$. Likewise, water clarity was more responsive to decreases in phosphorus loading than to increases in loading (fig. 16). With a decrease in phosphorus loading of 50 percent, Secchi depths increased by about $1.7 \mathrm{ft}$ (27 percent); however, with a 50-percent increase in loading, Secchi depths decreased by only $0.6 \mathrm{ft}$ (10 percent).

Trophic state index values indicated that Pike Lake was borderline between mesotrophic and eutrophic (fig. 5). On the basis of simulation results with the models within WiLMS, about a 50-percent reduction in phosphorus loading from that measured in MY2000 would be required for the lake to be classified as mesotrophic with respect to all three characteristics (fig. 17). With a 25-percent increase or more in phosphorus loading, Pike Lake would be classified as eutrophic with respect to all three characteristics.

\section{Response in Water Quality to Specific Scenarios}

To predict how the water quality in Pike Lake should respond to specific scenarios, the phosphorus loadings in table 6 were input into the models within WiLMS and the results were adjusted for the slight modeling biases (tables 7 and 8).

\section{Changes in Inlet-to-Outlet Short-Circuiting}

On the basis of the simulations, if changes were made to the morphometry of the inlet marsh channel that completely eliminated short-circuiting, the summer-average phosphorus concentrations would almost double to over $0.040 \mathrm{mg} / \mathrm{L}$ (fig. 14), the average chlorophyll $a$ concentration would increase to more than $10 \mu \mathrm{g} / \mathrm{L}$ (fig. 15), and average Secchi depth would decrease to about 5 $\mathrm{ft}$ (fig. 16). If changes were made to the morphometry of the marsh channel that increased the efficiency of shortcircuiting of phosphorus to 75 percent (about the same as was measured in 1999), the summer-average phosphorus concentrations would decrease to about $0.018 \mathrm{mg} / \mathrm{L}$, 

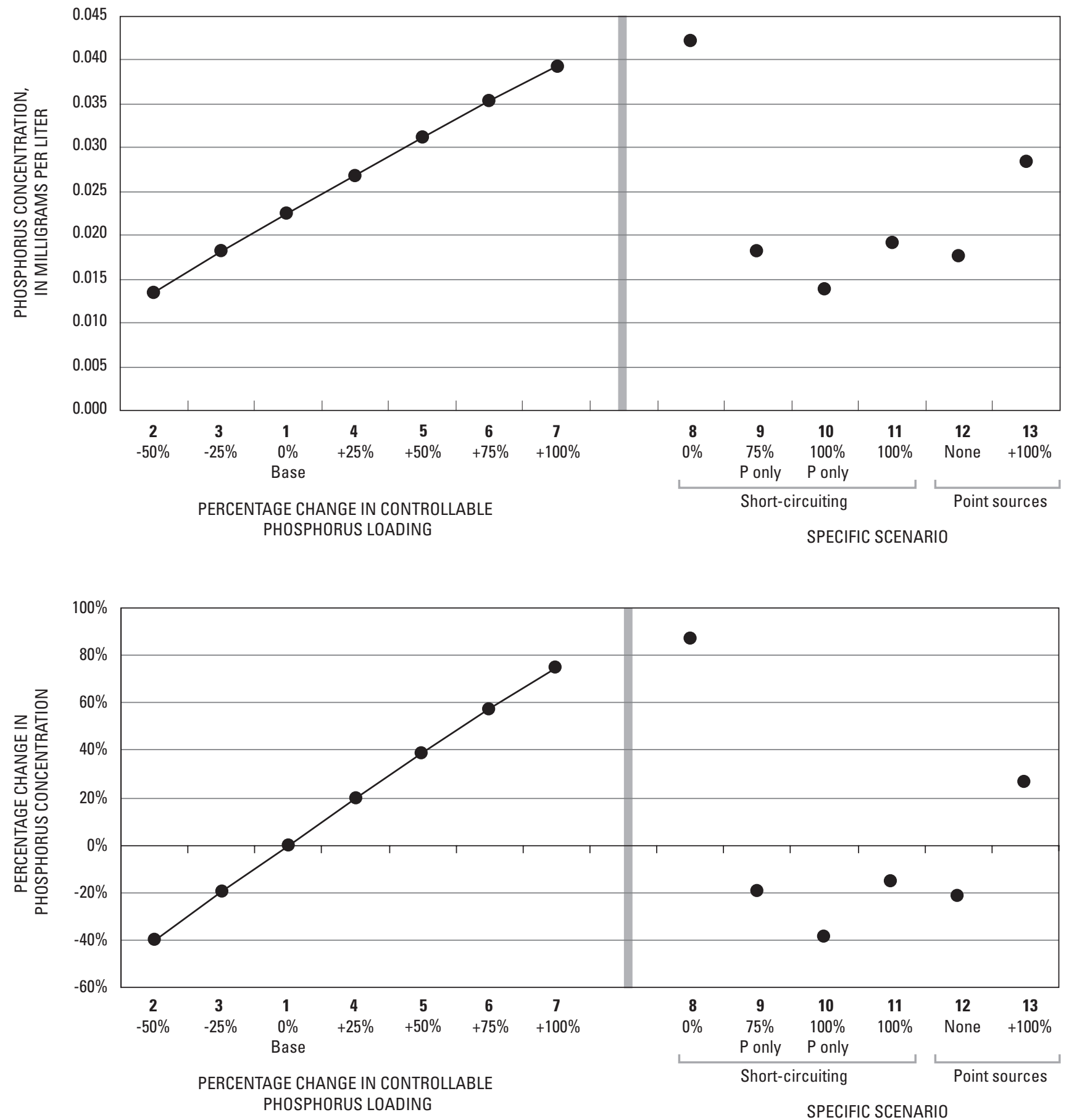

Figure 14. Simulated changes in near-surface total phosphorus (P) concentrations in Pike Lake near Hartford, Wis., with WiLMS (Wisconsin Lake Modeling Suite) in response to various phosphorus-loading scenarios. Bold numbers (1-13) preceding the $x$-axis labels correspond to the scenario identification numbers in table 6. 


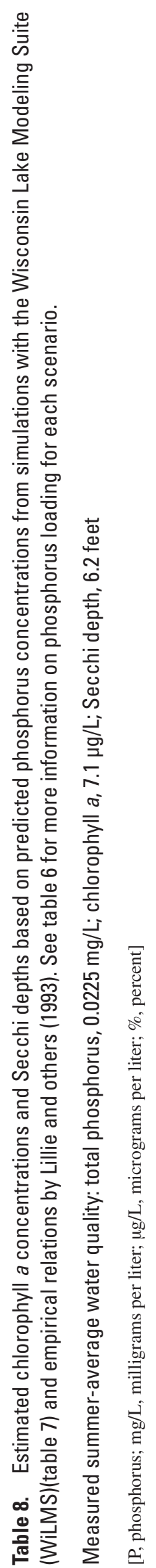

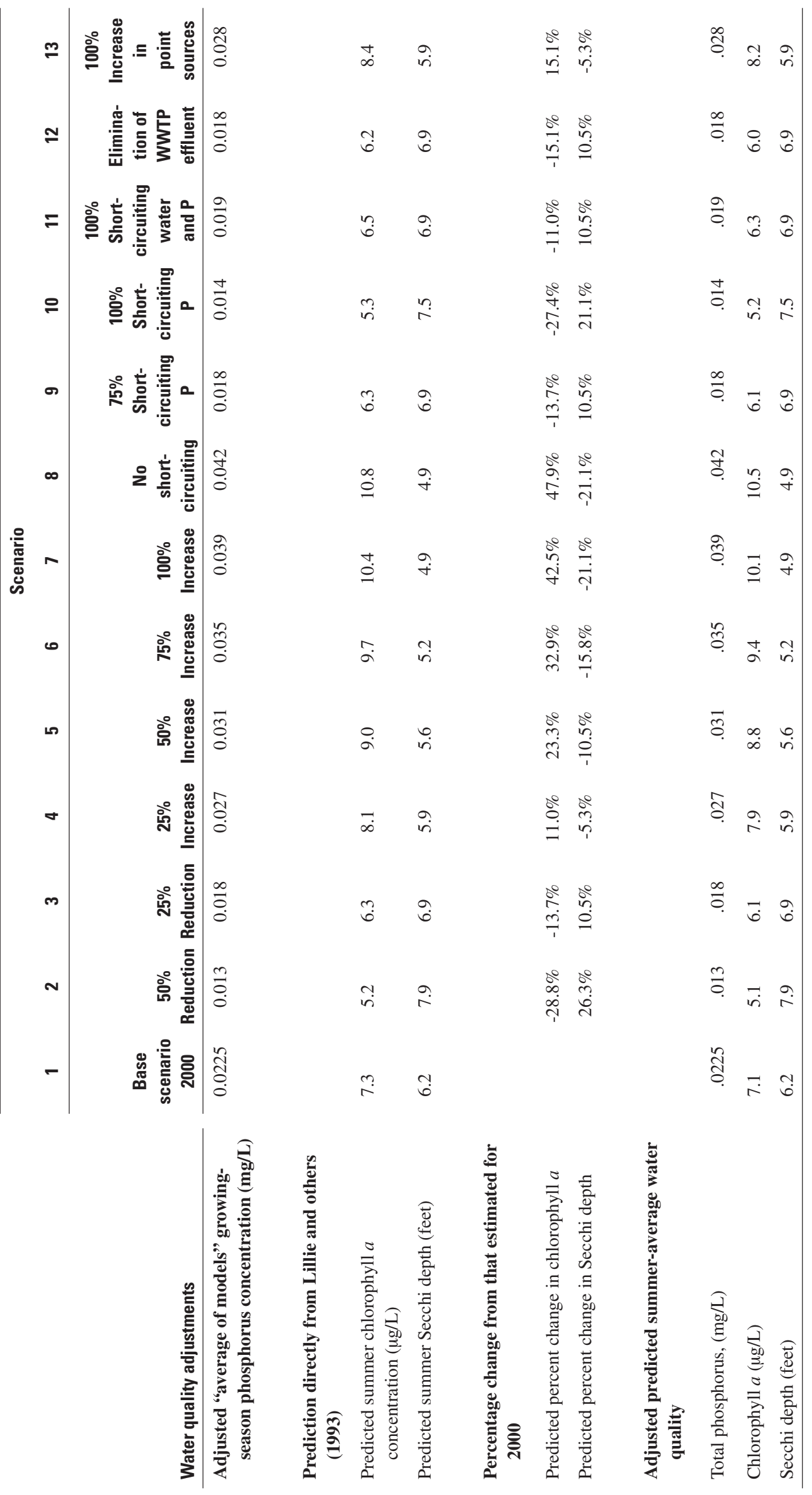



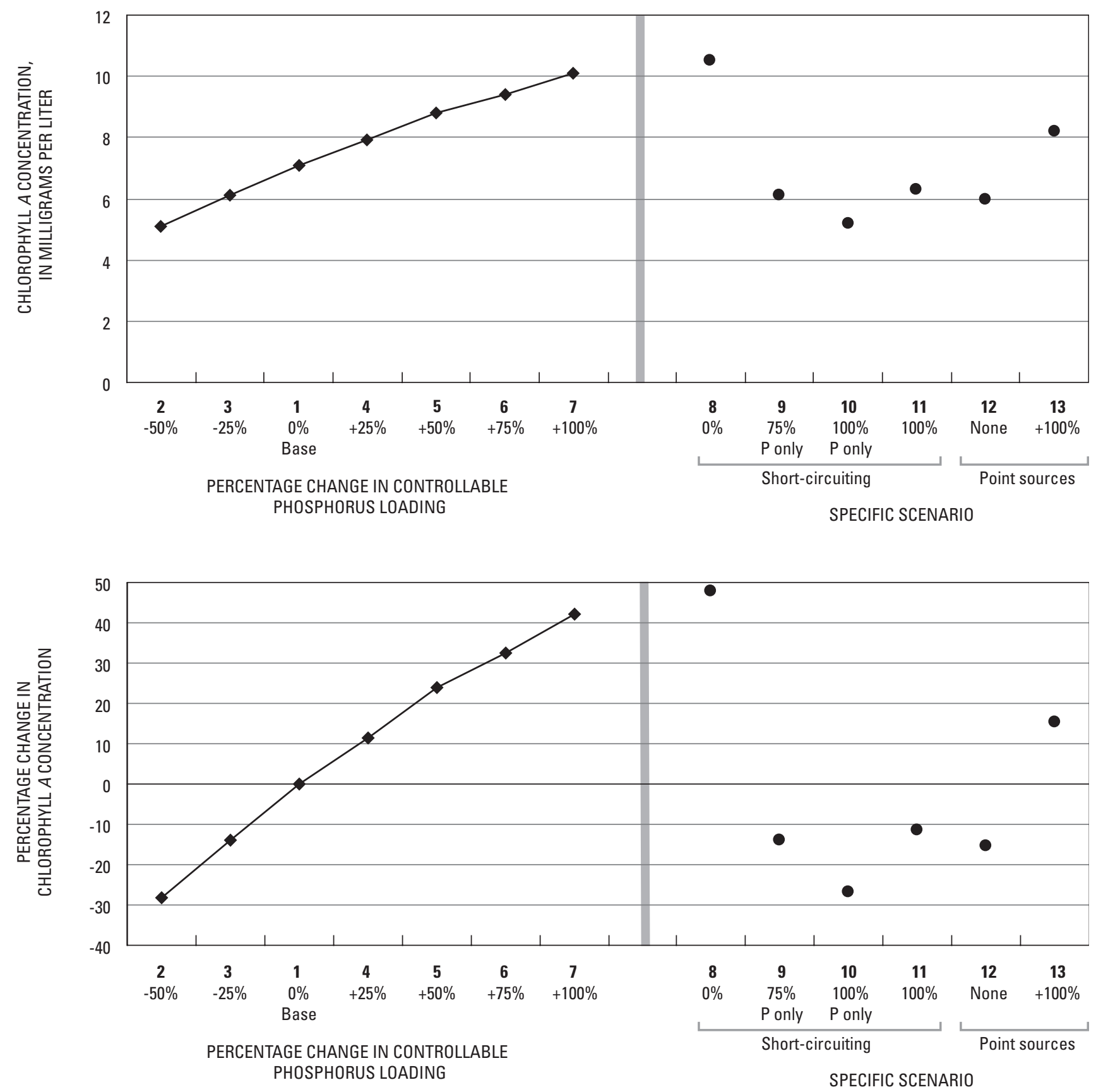

Figure 15. Simulated changes in near-surface chlorophyll a concentrations in Pike Lake near Hartford, Wis., with WiLMS (Wisconsin Lake Modeling Suite) in response to various phosphorus-loading scenarios. Numbers (1-13) preceding the $x$-axis labels correspond to the scenario identification numbers in table 6 . 

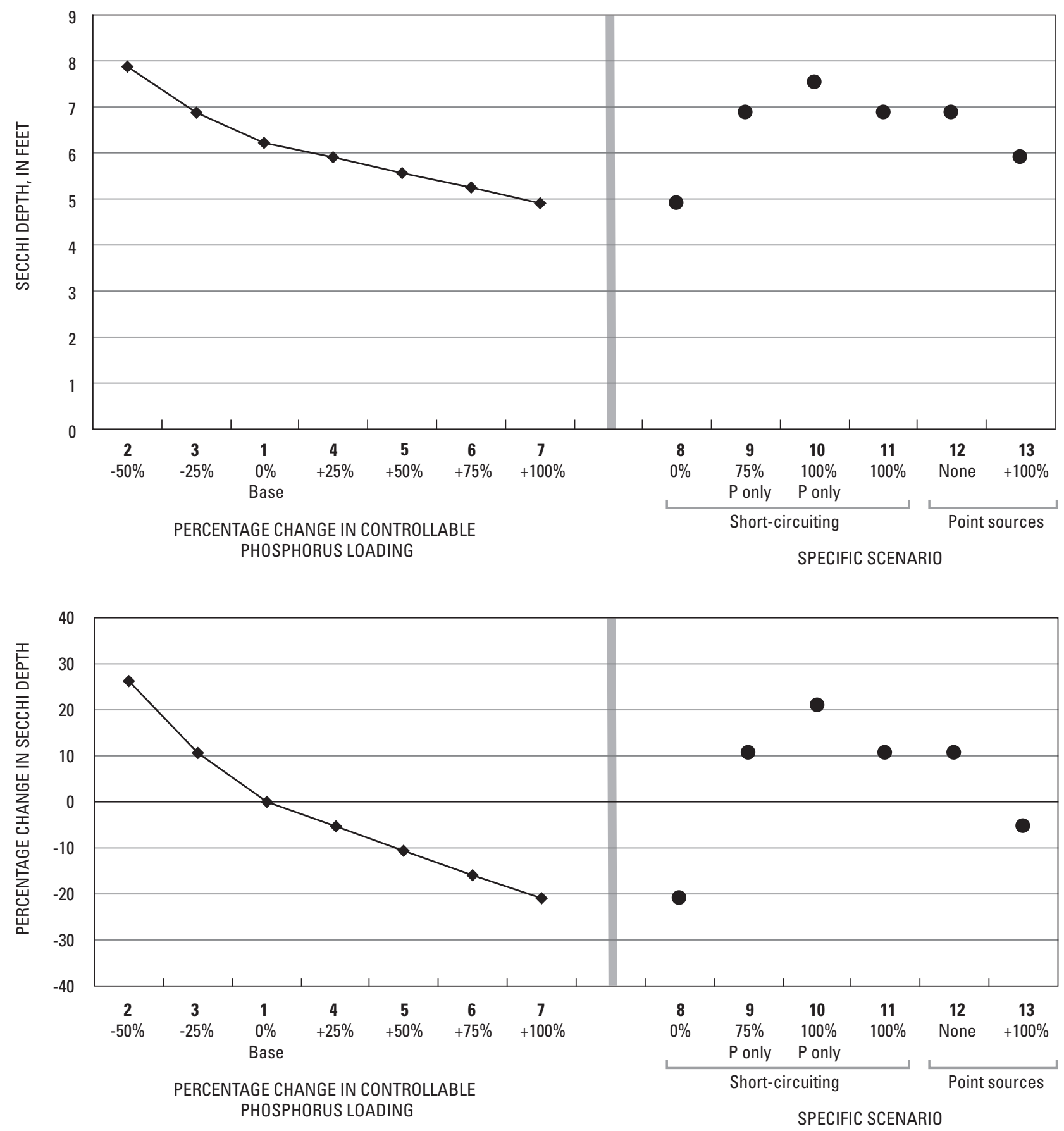

Figure 16. Simulated changes in Secchi depths in Pike Lake near Hartford, Wis., with WiLMS (Wisconsin Lake Modeling Suite) in response to various phosphorus-loading scenarios. Numbers (1-13) preceding the $x$-axis labels correspond to the scenario identification numbers in table 6. 


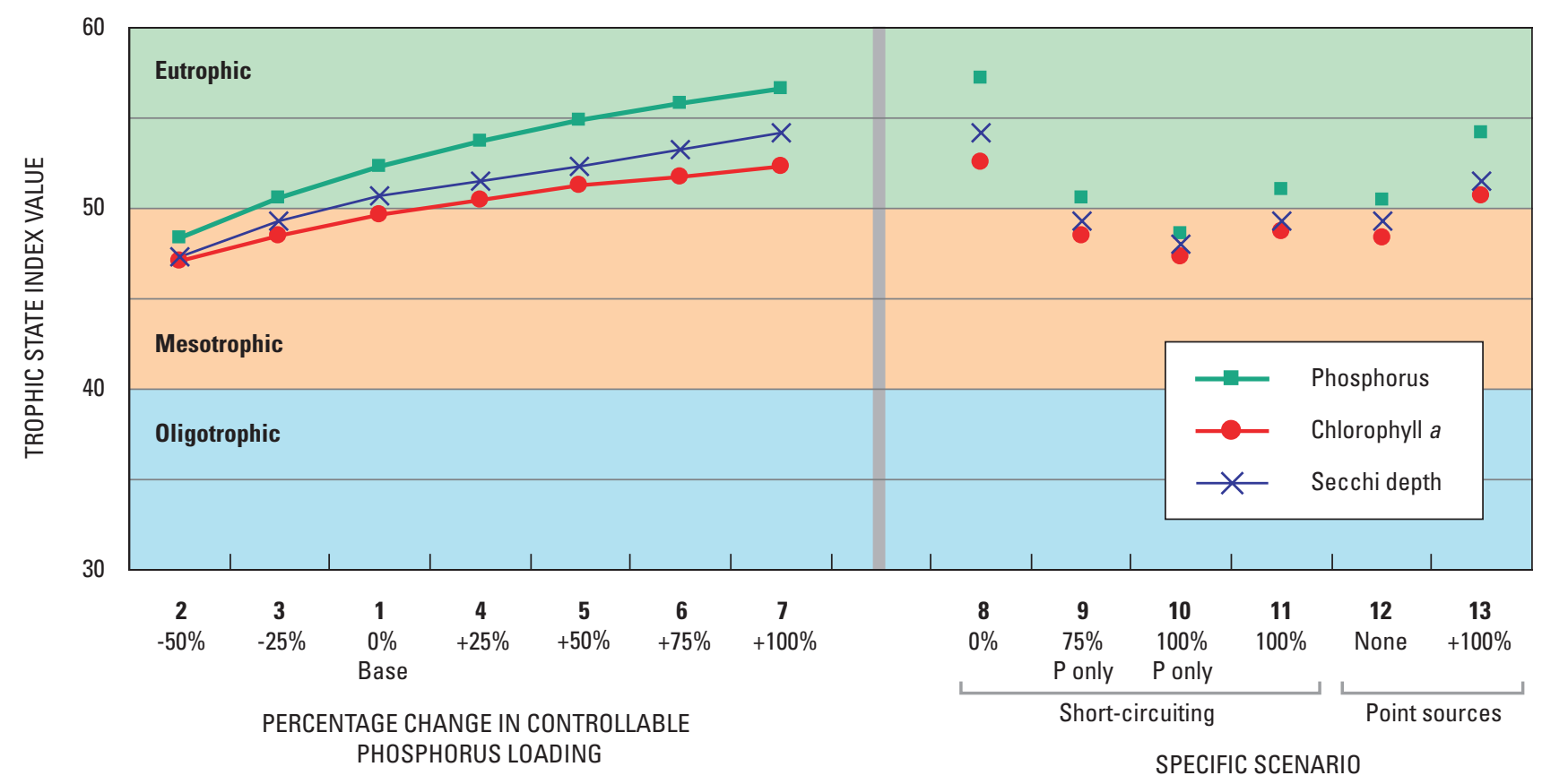

Figure 17. Simulated changes in trophic state index values for Pike Lake near Hartford, Wis., with WiLMS (Wisconsin Lake Modeling Suite) in response to various phosphorus-loading scenarios. Numbers (1-13) preceding the $x$-axis labels correspond to the scenario identification numbers in table 6.

average chlorophyll $a$ concentration would decrease to about $6 \mu \mathrm{g} / \mathrm{L}$, and average Secchi depth would increase to about $7 \mathrm{ft}$. If changes were made to the inlet to completely eliminate the input of phosphorus (for example, through the use of an alum-drip system) but allow the water to flow unchanged, the summer-average phosphorus concentrations would decrease to about $0.014 \mathrm{mg} / \mathrm{L}$, average chlorophyll $a$ concentration would decrease to about $5 \mu \mathrm{g} / \mathrm{L}$, and average Secchi depth would increase to about $7.5 \mathrm{ft}$. However, if the phosphorus and the water in the Rubicon River were completely diverted from the lake, the averagesummer phosphorus concentrations would only decrease to about $0.019 \mathrm{mg} / \mathrm{L}$, average chlorophyll $a$ concentration would decrease to about $6 \mu \mathrm{g} / \mathrm{L}$, and average Secchi depth would increase to about $7 \mathrm{ft}$. The smaller changes caused by the complete diversion of the Rubicon River were caused by the increased residence time of water and phosphorus in the lake associated with less inflow.

On the basis of these scenarios, only a 100-percent elimination of phosphorus from the Rubicon River would result in the lake being classified as mesotrophic on the basis of all three indices. However, even a slight increase in short-circuiting efficiency to 75 percent would result in chlorophyll $a$ concentrations and Secchi depths indicative of mesotrophic conditions.
Since completing the short-circuiting/dredging project through the marsh on the north end of the lake in the fall of 1995 (fig. 2), summer-average phosphorus concentrations have fluctuated and may have increased slightly (fig. 4). The slight increase in phosphorus concentrations may be due to the diversion channel filling with sediment and a new channel to the lake developing near the original channel, both of which may have decreased the short-circuiting efficiency.

\section{Changes in Point-Source Contributions}

To predict how changes in point-source contributions from the Slinger WWTP would influence the water quality of the lake, three scenarios were simulated: elimination of all effluent, 2000 base case, and doubling of the phosphorus in the effluent. On the basis of these scenarios, if WWTP effluent was completely eliminated, the summer-average phosphorus concentrations should decrease to about $0.018 \mathrm{mg} / \mathrm{L}$, average chlorophyll $a$ concentration would decrease to about $6 \mu \mathrm{g} / \mathrm{L}$, and average Secchi depth would increase to about $6.9 \mathrm{ft}$. These changes are similar to those expected with about a 25 -percent reduction in all controllable phosphorus inputs and would result in the lake being classified as mesotrophic with respect to chlorophyll $a$ concentrations and Secchi depth. If, however, phospho- 
rus input from the point source doubles (increases by 100 percent), the summer-average phosphorus concentrations would increase to about $0.028 \mathrm{mg} / \mathrm{L}$, average chlorophyll $a$ concentration would increase to about $8 \mu \mathrm{g} / \mathrm{L}$, and average Secchi depth would decrease to about $5.9 \mathrm{ft}$. These changes are similar to those expected with about a 25-percent increase in all controllable phosphorus inputs. Although the total input of phosphorus from point sources (WWTP) represented 43 percent of the total input to the lake in 2000 (table 4), the short-circuiting of phosphorus out of the lake reduces the effective input to only about one third of the total input. In other words, short-circuiting significantly reduces the potential impact of the point sources on Pike Lake.

\section{Changes in Land Use}

Changes in land use in the Pike Lake watershed could affect the water quality of the lake. Presently, the watershed is dominated by agricultural land use. If areas with less phosphorus export replace the agricultural areas, the water quality of the lake could improve. However, if the agricultural areas are replaced by high-density urban areas (with higher phosphorus export rates) or replaced with poorly maintained transitional areas, the water quality of the lake could deteriorate.

\section{Summary and Conclusions}

Pike Lake near Hartford, Wisconsin is classified as borderline mesotrophic to eutrophic. Because of concerns about the water quality of the lake, a cooperative study with the Pike Lake Protection and Rehabilitation District and the Wisconsin Department of Natural Resources was conducted by the U.S. Geological Survey during 1998 to 2000. The goals of the study were to evaluate the water quality of the lake in terms of long-term trends from 1970s to the present, to quantify the sources of phosphorus to the lake because productivity in the lake is phosphoruslimited, and to determine how the lake would respond to changes in phosphorus loading. Little overall change in water quality has been measured in the lake since data collection began except for increased concentrations of chloride and sodium. These increases were probably caused by the use of salt for deicing roads and increasing use of domestic water softeners as residential uses increase in the watershed.

A water budget constructed for MY1999 and MY2000 indicated that the major sources of water to the lake are the Rubicon River (about 55 percent), ungaged near-lake inflows (about 20 percent), precipitation (about 17 percent), and ground water (about 7 percent). The major output of water from the lake was through the outlet to the Rubicon River (about 87 percent) and secondarily from evaporation (about 13 percent).

Phosphorus budgets also were constructed for MY1999 and MY2000. The total annual input of phosphorus to Pike Lake was about 3,500 lbs and 2,400 lbs in MY1999 and MY2000, respectively. The major source of phosphorus was from the Rubicon River, which was about equally partitioned into that from the watershed and that from the Slinger WWTP; each source contributed about 40 percent of the total load of phosphorus. Most of the remaining phosphorus input was from the ungaged nearlake areas (about 18 percent). Precipitation and ground water were estimated to collectively contribute less than 5 percent of the total phosphorus load.

It was estimated that between 65 percent (MY2000) and 77 percent (MY1999) of the phosphorus contributed by the Rubicon River was short-circuited through the marsh on the north end of the lake and never reached the main body of the lake. Therefore, the net effective phosphorus input to the lake was about 1,400 lbs in MY1999 and about 1,200 lbs in MY2000.

Several water-quality models within the Wisconsin Lake Model Suite (WiLMS) (Panuska and Kreider, 2002) were used to simulate how the lake would respond to changes in phosphorus loading and simulate the expected changes in water quality in response to specific phosphorus-loading scenarios. Simulation results indicated that total phosphorus concentrations increase almost linearly with an increase in phosphorus loading, but changes in in-lake concentrations are not expected to be as large as the changes in phosphorus loadings. Results also indicated that chlorophyll $a$ concentrations and water clarity are more responsive to decreases in phosphorus loading than to increases in loading. About a 50-percent reduction in phosphorus loading is required for the lake to achieve a mesotrophic classification with respect to phosphorus and chlorophyll $a$ concentrations and Secchi depth.

Model simulations indicated that short-circuiting of flow through a diversion channel was the main reason why the water quality is as good as it is given the total phosphorus loading from the Rubicon River. Since constructing the diversion channel on the north side of the lake in 1995, summer-average phosphorus concentrations have fluctuated and may have increased slightly because of the marsh channel filling with sediment and a new channel to the lake developing near the original channel. Without short-cir- 
cuiting, the lake's phosphorus concentrations could double. If short-circuiting of phosphorus could be made more efficient, the water quality of the lake would improve.

Model simulations also show that effluent from the Slinger WWTP influences the water quality of the lake, but the short-circuiting of flow limits its effect. Presently, point sources have caused the phosphorus concentration to increase about $0.004 \mathrm{mg} / \mathrm{L}$. If loading from point sources was to double, the summer-average phosphorus concentrations in the lake should increase by about $0.006 \mathrm{mg} / \mathrm{L}$, and result an increase in the average chlorophyll $a$ concentration to about $8 \mu \mathrm{g} / \mathrm{L}$ and decrease in the average Secchi depth to about $5.9 \mathrm{ft}$.

Although the water quality of Pike Lake has not changed appreciably in recent years, results from WiLMS modeling demonstrate the sensitivity of the water quality in the lake to changes in phosphorus loading. The simulation results indicate that phosphorus loading to the lake is strongly affected by the extent of inlet-to-outlet shortcircuiting of flow from the Rubicon River and by loading from point and nonpoint sources.

\section{References Cited}

Carlson, R.E., 1977, A trophic state index for lakes: Limnology and Oceanography, v. 22, p. 361-369.

Correll, D.L., 1998, The role of phosphorus in the eutrophication of receiving waters-A review: Journal of Environmental Quality, v. 27, p. 261-266.

Corsi, S.R., Graczyk, D.J., Owens, D.W., and Bannerman, R.T., 1997: U.S. Geological Survey Fact Sheet FS-19597, 4 p.

Edwards, T.K., and Glysson, G.D., 1999, Field methods for measurement of fluvial sediment: U.S. Geological Survey Techniques of Water-Resources Investigations, book 3, chap. C2, 89 p.

Farnsworth, R.K., and Thompson, E.S., 1982, Mean monthly, seasonal, and annual pan evaporation for the United States: National Oceanic and Atmospheric Administration Technical Report NWS 34, 82 p.

Farnsworth, R.K., and Thompson, E.S., and Peck, E.L., 1982, Evaporation atlas for the contiguous 48 United States: National Oceanic and Atmospheric Administration Technical Report NWS 33, 27 p., 4 maps.
Field, S.J., and Duerk, M.D., 1988, Hydrology and water quality of Delavan Lake in southeastern Wisconsin: U.S. Geological Survey Water-Resources Investigations Report 87-4168, 61 p.

Hem, J.D., 1989, Study and interpretation of the chemical characteristics of natural water: U.S. Geological Survey Water Supply Paper 2254, third edition, 263 p.

King, H.W., and Brater, E., 1963, Handbook of hydraulics for the solution of hydrostatic and fluid-flow problems: McGraw-Hill Book Company, Inc., New York.

Lillesand, T., Chipman, J., Nagel, D., Reese, H., Bobo, M., and Goldman, R., 1998, Upper Midwest GAP analysis image processing protocol: Onalaska, Wis., U.S. Geological Survey, Environmental Management Technical Center, EMTC 98-G00, 25 p.

Lillie, R.A., and Mason, J.W., 1983, Limnological characteristics of Wisconsin lakes: Wisconsin Department of Natural Resources Technical Bulletin No. 138, 116 p.

Lillie, R.A., Graham, Susan, and Rasmussen, Paul, 1993, Trophic state index equations and regional predictive equations for Wisconsin Lakes: Wisconsin Department of Natural Resources Research Management Findings, no. 35,4 p.

Panuska, J.C., and Kreider, J.C., 2002, Wisconsin lake modeling suite program documentation and user's manual, Version 3.3 for Windows: Wisconsin Department of Natural Resources PUBL-WR-363-94, 32 p. [Available online through the Wisconsin Lakes Partnership: accessed on May 29, 2003, at URL http://www.dnr. state.wi.us/org/water/fhp/lakes/laketool.htm]

Porterfield, George, 1972, Computation of fluvial-sediment discharge: U.S. Geological Survey Techniques of Water Resources Investigations, book 3, chap. C3, 66 p.

Robertson, D.M., Goddard, G.L, Mergerer, E.A., Rose, W.J., and Garrison, P.J., 2002, Hydrology and water quality of Geneva Lake, Walworth County, Wisconsin, U.S. Geological Survey Water Resources Investigations Report 02-4039, 73 p.

Saad, D.A., 1997, Effects of land use and geohydrology on the quality of shallow ground water in two agricultural areas in the Western Lake Michigan drainages, Wisconsin: U.S. Geological Survey Water Resources Investigations Report 96-4292, 69 p.

U.S. Geological Survey, Wisconsin District Lake-Studies Team, 2001, Water-quality and lake-stage data for Wisconsin lakes, water year 2000: U.S. Geological Survey Open-File Report 01-86, 128 p. 
Waschbusch, R.J., Olson, D.L., Ellefson, B.R., and Stark, P.A., 2001, Water-resources data-Wisconsin, water year 2000: U.S. Geological Survey Water-Data Report WI-01-1, $560 \mathrm{p}$.

Wisconsin Department of Natural Resources, 1992, Wisconsin water quality assessment-Report to Congress, 1992: Publ-WR254-92-REV, 220 p.

Wisconsin Department of Natural Resources, 2001, Wisconsin Lakes: PUB-FH-800, 180 p.

Wisconsin State Laboratory of Hygiene, Environmental Sciences Section, 1993, Manual of analytical methods, inorganic chemistry unit: Wisconsin State Laboratory of Hygiene, revised November 1993 [variously paginated]. 
8 Printed on recycled paper 